\title{
A new Heraclides swallowtail (Lepidoptera, Papilionidae) from North America is recognized by the pattern on its neck
}

\author{
Kojiro Shiraiwa', Qian Cong 3 , Nick V. Grishin ${ }^{2,3}$ \\ I 12416 Picrus Street, San Diego, CA, USA 921292 Howard Hughes Medical Institute 3 Departments \\ of Biophysics and Biochemistry, University of Texas Southwestern Medical Center, 5323 Harry Hines Blvd, \\ Dallas, TX, USA 75390-9050
}

Corresponding author: NickV. Grishin (grishin@chop.swmed.edu)

Academic editor: Carlos Peña | Received 8 September 2014 | Accepted 4 December 2014 | Published 23 December 2014

http://zoobank.org/75E08F19-D459-49C0-8C3F-288514E812D2

Citation: Shiraiwa K, Cong Q, Grishin NV (2014) A new Heraclides swallowtail (Lepidoptera, Papilionidae) from North America is recognized by the pattern on its neck. ZooKeys 468: 85-135. doi: 10.3897/zookeys.468.8565

\begin{abstract}
Heraclides rumiko Shiraiwa \& Grishin, sp. n. is described from southwestern United States, Mexico, and Central America (type locality: USA, Texas, Duval County). It is closely allied to H. cresphontes (Cramer, $1777)$ and the two species are sympatric in central Texas. The new species is diagnosed by male genitalia and exhibits a nearly $3 \%$ difference from $H$. cresphontes in the COI DNA barcode sequence of mitochondrial DNA. The two Heraclides species can usually be told apart by the shape and size of yellow spots on the neck, by the wing shape, and the details of wing patterns. "Western Giant Swallowtail" is proposed as the English name for H. rumiko. To stabilize nomenclature, neotype for Papilio cresphontes Cramer, 1777, an eastern United States species, is designated from Brooklyn, New York, USA; and lectotype for Papilio thoas Linnaeus, 1771 is designated from Suriname. We sequenced DNA barcodes and ID tags of nearly 400 Papilionini specimens completing coverage of all Heraclides species. Comparative analyses of DNA barcodes, genitalia, and facies suggest that Heraclides oviedo (Gundlach, 1866), reinstated status, is a species-level taxon rather than a subspecies of $H$. thoas (Linnaeus, 1771); and H. pallas (G. Gray, [1853]), reinstated status, with its subspecies H. p. bajaensis (J. Brown \& Faulkner, 1992), comb. n., and Heraclides anchicayaensis Constantino, Le Crom \& Salazar, 2002, stat. n., are not conspecific with H. astyalus (Godart, 1819).
\end{abstract}

\section{Keywords}

Biodiversity, cryptic species, DNA barcodes, Neotropical, Heraclides homothoas, Heraclides melonius, butterfly release, APHIS

Copyright Kojiro Shiraiwa et al. This is an open access article distributed under the terms of the Creative Commons Attribution License (CC BY 4.0), which permits unrestricted use, distribution, and reproduction in any medium, provided the original author and source are credited. 


\section{Introduction}

Swallowtails (Papilionidae Latreille, [1802]) are arguably the best-known and beststudied butterflies due to their large size, dazzling colors, and elegant shapes. Despite significant research efforts, the family is still plagued with taxonomic difficulties and is rich in evolutionary puzzles (Zakharov et al. 2004, Kawahara and Breinholt 2014). From the origins of mimicry to speciation through hybridization, swallowtails are becoming a model group for evolutionary biology and genomics (Kunte et al. 2011, Zhang et al. 2013, Kunte et al. 2014). Groundbreaking work of Rothschild and Jordan (1906) established the foundation for the classification and future studies of Neotropical Swallowtails. Pioneering molecular studies by Sperling's group shed light on their phylogeny and speciation, and revealed unsuspected complexities in relationships within the family (Sperling and Harrison 1994, Caterino and Sperling 1999, Zakharov et al. 2004, Simonsen et al. 2011). Tyler, Brown and Wilson (1994) summarized the knowledge on American Papilionidae in an amazingly instructive and compact volume. Nevertheless, the family is continuing to surprise us with its complexity and nuances (Lewis et al. 2014).

A multifaceted pattern of speciation resulted in 7 or 8 species of tiger swallowtails (Pterourus glaucus group) in North America (Kunte et al. 2011, Warren et al. 2014). The most remarkable of recent discoveries was the description of Pt. appalachiensis Pavulaan \& D. Wright, 2002, which is a hybrid species recently originated through gene exchange between Pt. canadensis (Rothschild \& Jordan, 1906) and Pt. glaucus (Linnaeus, 1758) (Pavulaan and Wright 2002, Kunte et al. 2011, Zhang et al. 2013). Pt. canadensis was originally proposed as a subspecies of Pt. glaucus, but is treated today as a biologically distinct species differentiated from Pt. glaucus about 600,000 years ago (Zhang et al. 2013). While the two species can hybridize over the narrow zone where they meet, they show significant divergence in a number of characters, both in genotype and phenotype (Hagen et al. 1991, Ording 2008, Ording et al. 2009, Winter and Porter 2010, Kunte et al. 2011, Zhang et al. 2013).

The Giant Swallowtails (Heraclides cresphontes group sensu Fig. 15, see below for more detailed definition) has received less attention. Currently treated as three species: H. cresphontes (Cramer, 1777) distributed from Canada to Panama; H. homothoas (Rothschild \& Jordan, 1906) recorded from Costa Rica to Venezuela and Trinidad; and H. melonius (Rothschild \& Jordan, 1906), a Jamaican endemic, these butterflies are closely related to $H$. thoas (Linnaeus, 1771) with its seven described subspecies ranging from Texas and Cuba to Uruguay and Argentina, and $H$. paeon (Boisduval, 1836), consisting of three named subspecies known from Yucatan to Chile and Bolivia (Tyler et al. 1994, Lamas 2004, Warren et al. 2014). In agreement with Lewis et al. (2014), we find that the Greater Antilles endemics H. aristor (Godart, 1819) and $H$. caiguanabus (Poey, [1852]) are closely allied to the above-mentioned species, despite their striking difference in appearance due to the lack of a central band on their wings.

In 2005, KS collected several specimens of $H$. cresphontes on lantana flowers near an orange orchard grove in Pauma Valley, San Diego County, California. Comparison 
with $H$. cresphontes specimens from Silver Lake, Kosciusko County, Indiana revealed wing pattern differences between California and Indiana populations. Several years ago, with the accumulation of COI DNA barcode sequences in databases, NVG noticed that the only available sequence of $H$. cresphontes from northeastern USA (Caterino and Sperling 1999) differed by about 3\% from $H$. cresphontes sequences from Costa Rica (Ratnasingham and Hebert 2007). While provoking, it was unclear how DNA sequences vary with large geographic distances. These anecdotal observations prompted further investigation. Dissection of male genitalia of $H$. cresphontes from across its range revealed two groups consistent with pattern differences. Eastern $H$. cresphontes differed from southwestern ones. DNA barcode sequences of $200 \mathrm{H}$. cresphontes specimens from Canada to Panama and from California to Florida also fell in two sequence groups: the eastern and the southwestern haplotypes. There was very little variation within each haplotype group, but a 3\% difference between the groups. Both haplotypes were present in central Texas. These results on correlation between genitalia, patterns and DNA barcodes suggested that the butterfly known as H. cresphontes is a complex of two cryptic species, one of which was unnamed and is described herein.

\section{Materials and methods}

Specimens used in this study were collected in the field under the permit \#08-02Rev from Texas Parks and Wildlife Department to NVG, or examined in the following collections: Texas A\&M University Collection, College Station, TX, USA (TAMU); University of Texas at Austin Insect Collection, Austin, TX, USA (TMMC); National Museum of Natural History, Smithsonian Institution, Washington, DC, USA (USNM); Colorado State University Collection, Fort Collins, CO, USA (CSUC); The Field Museum of Natural History, Chicago, IL, USA (FMNH); American Museum of Natural History, New York, NY, USA (AMNH); McGuire Center for Lepidoptera and Biodiversity; Gainesville, FL, USA (MGCL); San Diego Natural History Museum, San Diego, CA, USA (SDMC); and Los Angeles County Natural History Museum, Los Angeles, CA, USA (LACM) and several private collections. Standard entomological techniques were used for dissection (Robbins 1991), i.e., the abdomen or its distal part was broken off, soaked for 40 minutes (or until cleared) in $10 \% \mathrm{KOH}$ at $60^{\circ} \mathrm{C}$, dissected, and subsequently stored in a small glycerol-filled vial on the pin under the specimen. Genitalia and wing venation terminology follows Miller (1987) and Lewis (2010). Length measurements are in metric units and were made from photographs of specimens taken with a scale and magnified on a computer screen. Photographs of immature stages and specimens were taken with a Nikon D800 camera through a $105 \mathrm{~mm}$ f/2.8G AF-S VR Micro-Nikkor lens; dissected genitalia were photographed in glycerol with a Nikon D80 through $105 \mathrm{~mm}$ f/2.8G AF-S VR Micro-Nikkor lens and Nikon D200 camera without a lens and through microscopes at $1.5 \times-3 \times$ magnification. Images were assembled and edited in Photoshop CS5.1. Genitalic photographs were taken in several focus slices and stacked in Photoshop and Zerene Stacker to increase depth of field. 
Legs (cut with scissors into tiny pieces in lysis buffer), crumbs and pieces of muscle tissue from the thorax of dissected specimens (plucked from the abdomen attachment site), or a distal part of an abdomen (dropped into lysis buffer, and after overnight incubation at $56^{\circ} \mathrm{C}$ transferred into $10 \% \mathrm{KOH}$ for genitalia dissection) were used to extract genomic DNA with Macherey-Nagel (MN) NucleoSpin ${ }^{\odot}$ tissue kit following the manufacturers protocol. The lysis buffer volume was scaled down to $70 \mu \mathrm{l}$ for legs and volumes of subsequent reagents were proportionally reduced. Genomic DNA was eluted in a total volume of 40-100 $\mu \mathrm{l}$ MN BE buffer (concentration of DNA as measured by Promega QuantiFluor ${ }^{\circ}$ dsDNA System was from near 0 to $20 \mathrm{ng} / \mu \mathrm{l}$, mostly around $1 \mathrm{ng} / \mu \mathrm{l}$, depending on specimen age and storage conditions) and was stored at $-20^{\circ} \mathrm{C}$.

PCR was performed using Invitrogen AmpliTaq Gold 360 master mix in a $20 \mu \mathrm{l}$ total volume containing less than $1 \mathrm{ng}$ of template DNA (usually $0.5-1 \mu \mathrm{l}$ of DNA extract) and $0.5 \mu \mathrm{M}$ of each primer. For legs from freshly collected specimens or those preserved in alcohol, the following primers were used to obtain the complete barcode: LepF: 5'-TGTAAAACGACGGCCAGTATTCAACCAATCATAAAGATATTGG-3' and LepR: 5'-CAGGAAACAGCTATGACCTAAACTTCTGGATGTCCAAAAAATCA-3'. For older specimens (up to 1960) the following pairs of primers were used: swtl-COIF (forward, 5'-TTATTCAACAAATCATAAAGATATCGGA-3') - swtlmCOIR (reverse, 5'-GTTCCKGCYCCATTTTCTAC-3'), or sCOIF (forward, 5'-ATTCAACCAATCATAAAGATATTGG-3') - smCOIR (reverse, 5'-CCTGTTCCAGCTCCATTTTC-3'), and swtl-mCOIF (forward, 5'-GACTTTTACCCCCTTCTCTAACTC-3') - swtl-COIR (reverse, 5'-AAAATATAAACTTCAGGATGTCCAAA-3'), to amplify the barcode in two overlapping segments.

The barcodes of even older specimens (1900-1960) were amplified in four overlapping segments with the following four pairs of Heraclides-specific primers: paeonCOIF (forward, 5'-TCAACAAATCATAAAGATATCGGAAC-3') - swtl-bCOIR (reverse, 5'-AATCAATTTCCAAATCCTCCAA-3'), swtl-bCOIF (forward, 5'-CCGGCTCATTAATTGGAGATG-3') - swtl-mCOIR (reverse, 5'-CTGTTCCKCTYCCATTTTCTAC-3'), swtl-mCOIF2 (forward, 5'-TTTTGACTTTTACCCCCTTCTCTAA-3') - swtl-eCOIR (reverse, 5'-CCTACGGCTCAAACAAATAAAGG-3'), and swtl-eCOIF (forward, 5'-TTCCTCAATTCTTGGRGCAATTA-3') swtl-COIR2 (reverse, 5'- AAAATATAAACTTCAGGATGTCCAAAAA -3'). In case of failure, additional primers that match target sequences better were used, as specified in GenBank entries for these sequences (KP173713-KP174107) and barcodes were amplified in more than 4 segments.

For some old specimens (e.g., 1870-1960), amplification of longer DNA segments failed. To obtain their sequences for identification, we developed Heraclides-specific primers for very short, about 100 bp fragments, which we call ID tags. A region in which the two USA Heraclides species differ from each other the most, was selected and the following primers were designed: swtl-ID1F (forward, 5'-TGAGCAAGAATACTAGGAACTTCTCTTA-3') - swtl-ID1R (reverse, 5'-AATAAAAGCATGAGCTGTAACAATAGTA-3') to amplify 64 bp sequence from the specimen (together with both primers, the actual product is $120 \mathrm{bp}$ ). 
The PCR reaction was cleaned up by enzymatic digestion for the whole barcode amplifications, ID tag amplification, and sequences amplified in more than 2 segments, with $4 \mu \mathrm{l}$ Shrimp Alkaline Phosphatase $(20 \mathrm{U} / \mu \mathrm{l})$ and $1 \mathrm{ul}$ Exonuclease I (1 U/ $\mu l)$ from New England Biolabs. For sequences obtained in two segments, due to the frequent presence of primer dimers and other short non-specific PCR products, Agencourt Ampure XP beads or Invitrogen E-Gel ${ }^{\oplus}$ EX Agarose Gels (followed by Zymo gel DNA recovery kit) were used to select the DNA products of expected length. Sequences were obtained using the M13 primers (for amplification from LepF and LepR primers): 5'-TGTAAAACGACGGCCAGT-3' or 5'-CAGGAAACAGCTATGACC-3' or with primers used in PCR. Sanger sequencing was performed with Applied Biosystems Big Dye Terminator 3.1 kit on ABI capillary instrument in the DNA Sequencing Core Facility of the McDermott Center at UT Southwestern. The resulting sequence traces were proofread in FinchTV <http://www.geospiza.com/Products/finchtv.shtml>.

As a result, we obtained complete or partial DNA barcode sequences from 395 Papilionini specimens. Sequences and accompanying specimen data were submitted to GenBank and received accession numbers KP173713-KP174107. Data about these specimens are provided in Suppl. material 1.

Additional DNA sequences for analysis were downloaded from GenBank $<\mathrm{http}$ :// genbank.gov/> (Benson et al. 2014) using accession numbers provided in Lewis et al. (2014) or were found by BLAST <http://blast.ncbi.nlm.nih.gov/> searches (Altschul et al. 1990) using sequences obtained by us to query "nr/nt" database, or from the BOLD database <http://boldsystems.org> (Ratnasingham and Hebert 2007). All sequences were aligned manually since they matched throughout their length without insertions or deletions. For a quick reference, Phylogeny.fr server at <http://www. phylogeny.fr/> was used with the Hamming distance model (Dereeper et al. 2008) to compute evolutionary distances from aligned DNA sequences and BioNJ (Gascuel 1997) algorithm to build dendrograms. A more thorough analysis was performed on DNA alignments using an elaborate comparative protocol involving a battery of methods and locally installed programs. In the analysis, because there are no insertions or deletions in the barcodes of butterflies, gaps (e.g., missing or ambiguous base pairs, including terminal ones) were treated as missing characters. TNT (version 1.1, available with the sponsorship of the Willi Hennig Society) was used for Maximum parsimony reconstruction (Goloboff et al. 2008). "New technology search" algorithm was used with Sect. Search, Ratchet (10 iterations), Drift (10 cycles), and Tree Fusing options enabled. Both Bremer support (Bremer 1994) and Bootstrap values were computed and mapped on the trees with TNT. Maximum Likelihood analysis was performed using RAxML (version 7.0.4) under several substitution models, such as GTRCAT, GTRGAMMA, and GTRGAMMAI (Stamatakis 2006). Rapid RAxML bootstrap values (-x option, and "-f a" for complete analysis) were computed to judge about the confidence of tree nodes. Bayesian Inference was performed with MrBayes v3.2.1 (Huelsenbeck and Ronquist 2001, Ronquist and Huelsenbeck 2003). Models with 1, 2 and 6 states were used (nst=1,2,6), with optimized fraction of invariant positions (propinv), gamma distribution parameter (gamma) or both (invgamma). 
The COI alignment was treated as a single partition, or analyzed as 3 partitions by codon position. Generations were carried out until convergence (standard deviation of split frequencies less than 0.01 ) and the first $25 \%$ were discarded as "burn in". Posterior probabilities of nodes computed by MrBayes were used as the indicators of confidence.

\section{Results}

Comparison of $H$. cresphontes male genitalia throughout its range from Canada to Panama reveals two groups (Fig. 14). Specimens from the eastern group (Fig. 11B-D) possess shorter and more robust uncus arms. Brachium arms project from the base of uncus on the outer side and are mostly hidden under uncus in dorsal view. In lateral view, uncus and brachium point in the same direction. The bases of uncus and brachium are fused, brachium is stronger sclerotized at the base. Specimens from the southwestern group (Fig. 11b-d) are characterized by longer and more slender uncus arms, often strongly curving inwards. Brachium arms project from the base of uncus on the inner side, and are visible below uncus in dorsal view. In lateral view, uncus and brachium point away from each other: posterodorsad (uncus) and posteroventrad (brachium). The bases of uncus and brachium are weakly fused, with weaker sclerotization at the base of brachium.

Specimens from the eastern North America, from Canada to Florida and central Texas, USA belong to the eastern group. Specimens from other parts of the range from central Texas to California, USA and southwards to Panama belong to the southwestern group. In central Texas, both groups are present. Genitalic differences between groups correlate with the differences in facies (Fig. 11E, facies vs. genitalic differences on the plots). While facies are variable and some exceptions are found, the eastern group specimens have pale-yellow spots on the head, patagia, and thorax(Fig. 11A), but southwestern specimens are characterized by continuous yellow stripes instead (Fig. 11a). Southwestern specimens have generally narrower, less scalloped wings, longer and more slender hindwing tails, and exhibit statistical difference in details of wing patterns, mostly on ventral hindwing.

Correlation between genitalic and facies differences and geographic distribution suggests that we are dealing with two distinct evolutionary lineages diversified sufficiently to be treated as two taxonomic units. However, these units are mostly allopatric and overlap over narrow range in central Texas. Moreover, in the range of overlap, we see specimens with intermediate characters. Therefore, it was not clear whether to regard these taxonomic units as subspecies, or suggest that the divergence between them is sufficient for biological species.

To address this question, we determined COI mitochondrial DNA barcode sequences for $249 \mathrm{H}$. cresphontes-like specimens from over 100 localities covering the entire distribution range from Canada to Panama. The results were surprisingly clear-cut. Each specimen fell into one of the two groups: eastern and southwestern (Figs 17, 18). 
Within each group, variability in barcode sequences was very low, within $0.5 \%$, despite the range covering 3,000 miles, and was rather individual than geographic. E.g., specimens from San Diego, California (USA) had the same DNA barcode as those from the Cape region in Baja California Sur (Mexico), Yucatan (Mexico), or near Panama Canal (Panama). Between the two groups, there was a hiatus of nearly 3\%.

To put this number in perspective and compare it with divergence in other Papilionini Latreille, [1802], DNA barcode differences between $H$. androgeus (Cramer, 1775) and H. thersites (Fabricius, 1775), Pt. glaucus (Linnaeus, 1758) and Pt. canadensis (Rothschild \& Jordan, 1906), and Papilio polyxenes Fabricius, 1775 and P. zelicaon Lucas, 1852 are $2.9 \%, 2.1 \%$, and $3.4 \%$ respectively. Distances between these species from three Papilionini genera are of the same magnitude as the distance between eastern and southwestern $H$. cresphontes populations. On the other hand, barcode differences between Papilionini taxa regarded as subspecies are usually within $1.5 \%$, and mostly below 1\%. Three percent difference in the barcode suggests (April et al. 2013, Papadopoulou et al. 2009, Zhang et al. 2013) that the two H. cresphontes-like taxa diverged from each other from one to three million years ago, prior to divergence between $P$. glaucus and $P$. canadensis (about 600,000). Thus, it is likely that eastern and southwestern $H$. cresphontes populations have evolved in isolation long enough to fully speciate. These two species are mostly allopatric, and central plus southeastern Texas is the only region where we find them both.

However, it is conceivable that one of these two barcodes might have evolved not within this species, but could have been introgressed from a different, albeit closely related, species. If that were the case, it is possible that the two $H$. cresphontes-like taxa are not distinct as species, but one simply experienced introgression from a different species. For instance, many individuals of Erynnis propertius (Scudder \& Burgess, 1870) in California carry DNA barcode of E. horatius (Scudder \& Burgess, 1870) from eastern USA (Zakharov et al. 2009). To test whether the southwestern $H$. cresphontes-like barcode sequence might have been introgressed from some other Heraclides species, instead evolving within $H$. cresphontes populations, we obtained barcode sequences of eight $H$. homothoas and five $H$. melonius specimens from several localities (Suppl. material 1). These two taxa are from the same species group of Giant Swallowtails and are the closest extant relatives of $H$. cresphontes. Sequences of $H$. homothoas and $H$. melonius were different from each other $(2.6 \%)$ and from either of the $H$. cresphontes DNA barcodes (3\% to 3.5\%, differences of the same magnitude as those between the two $H$. cresphontes-like taxa). Barcode sequences were also obtained from all $H$. thoas subspecies and from $H$. paeon. These sequences were even more distant from the $H$ cresphontes group (more than $5 \%$ difference), but revealed unexpected peculiarities of their own. Thus, neither $H$. cresphontes-like sequence was introgressed from any extant Heraclides taxon, and the two sequences: eastern and southwestern, are each other's closest relatives.

Next, in a quest for the names to apply to the eastern and southwestern species, we analyze names proposed for $H$. cresphontes, search for type specimens, and stabilize nomenclature by designation of lectotypes and a neotype. 


\section{Lectotype designation for Papilio cresphontes Cramer, 1777}

P. cresphontes was described by Pieter Cramer (1777: 106, 107, Pl. CLXV A, CLXVI B) on the basis of several specimens collected "in Noord-Amerika, te Nieuwjork en op het Eiland Jamaika, als mede in Zuid-Carolina" (description on the left in Dutch), or "dans l'Amerique Septentrionale, a la Nouvelle-York \& dans l'Isle de la Jamaïque, comme aussi dans la Caroline Meridionale" (description on the right in French), which can be translated as "in North America, from New York and on the island of Jamaica, as well as in South Carolina." Thus, the type locality includes at least three distinct localities in North America: New York, Jamaica, and South Carolina. However, the species referred to as $H$. cresphontes in essentially all literature since Cramer does not normally occur in Jamaica, and the Jamaican records are either possible human imports or misidentifications (Tyler et al. 1994). The native Jamaican Giant Swallowtail has been described by Rothschild and Jordan (1906) as a different taxon, known today as $H$. melonius. Rothschild and Jordan (1906) referred to Cramer's description of $H$. cresphontes in their description of $H$. melonius, hence making the Jamaican syntype of $H$. cresphontes simultaneously a syntype of $H$. melonius and the type series of $H$. cresphontes polytypic. Polytypic series of $H$. cresphontes has a potential for instability of nomenclature in the absence of a lectotype. To designate the lectotype, we studied the $H$. cresphontes type series further.

Cramer illustrated two specimens, a female in dorsal and ventral aspects (Cramer 1777: pl. CLXV A, ventral aspect figure erroneously referred to as "B" on page 107) and a male in dorsal aspect (Cramer 1777: pl. CLXVI B, page 107 states the ventral aspect of the male is similar to that of the female illustrated in pl. CLXV A). Published illustrations did not give precise localities of these specimens. Additionally, Cramer referenced a specimen illustrated by Daubenton (1765: 69). This specimen is equally a syntype. The engraving (Daubenton 1765: 69), masterfully performed by French artist Francois Nicolas Martinet (1725-1804) shows dorsal and ventral aspects of what was called "Le Festonne de la Gouadeloupe". Apparently, "Le Festonne" (The Scalloped), is a name given to this butterfly, and "la Gouadeloupe" could only mean the locality, i.e., Guadeloupe, a group of Caribbean islands, which today are an overseas region of France. Curiously, this specimen is also a syntype of $H$. thoas (Linnaeus, 1771), and its locality as "Guadalupa" is mentioned in the original description (Linnaeus 1771).

Since no Giant Swallowtails are known from Guadeloupe (Tyler et al. 1994), either this locality is erroneous, or the species illustrated has become extinct there. The engraving is consistent in most characters with the well-patterned spring form of eastern $H$. cresphontes. However, the prominent red-orange base of all three cells between veins $\mathrm{M}_{1}$ and $\mathrm{CuA}_{1}$ on ventral hindwing is a character diagnostic of $H$. melonius, currently known only from Jamaica. Thus, using published illustrations and texts we were not able to confidently associate any of the three illustrated syntypes with localities mentioned in the description of $H$. cresphontes.

We took the following steps to search for the $H$. cresphontes syntype specimens. First, we studied the literature. In a comprehensive search for the type specimens of 
Cramer taxa in the Natural History Museum, London (BMNH), John Chainey identified a possible syntype male (specimen number BMNH(E)\#665119, Figs 1-2). Unfortunately, the specimen does not bear any locality labels. Also, it is not any of the three syntypes discussed above: it is a male and it lacks 3 anterior yellow spots on the dorsal forewing. Finally, as Chainey noticed, it is not possible to say with any confidence that the specimen is indeed a syntype. Second, we contacted Rob de Vos, Lepidoptera collection manager at Naturalis Biodiversity Center (Leiden, Netherlands), where Cramer types for a number of taxa are cared for. The search for $H$. cresphontes syntypes in both collections_-Rijksmuseum van Natuurlijke Historie (RMNH) and Zoölogisch Museum Amsterdam (ZMAN), did not yield positive results. Rob wrote: "unfortunately no luck for a Cramer's cresphontes type. I'm afraid we do not have it. It may not exist anymore. Much of his collection has disappeared, probably lost, in private collections." Thus we were not able to find possible syntypes with locality labels to help select a single locality of several mentioned in the description of $H$. cresphontes.

Similar challenges with Cramer type localities and syntypes were encountered by other researchers, so negative results were not surprising. For instance, Clench and Miller (1980) found that "many of the species described by Cramer in De Uitlandsche Kapellen were based on specimens brought to him by seafarers, and Cramer accepted their locality labels as correct". Clench and Miller also examined possible shipping routes seafarers have taken and listed Jamaica, New York, Savannah and Chesapeake Bay as one of those possible routes, consistent with all the localities given by Cramer.

As a final resort, we consulted the original drawings by Gerrit Wartenaar Lambertz made for Cramer and used as prototypes for the published engravings. Presently, the drawings are in the library of the Natural History Museum, London (BMNH). One of the drawings for the Volume 2, "A" on the plate \#134, reproduced here as Fig. 3, was a prototype for Cramer's figure CLXVI B, male from the original description, reproduced here as Fig. 4. Interestingly, the caption to the Lambertz figure stated "Cresphontes male New York" (inset between Figs 3 and 4). The image portrays a specimen very consistent with the spring form of eastern $H$. cresphontes, with welldeveloped row of submarginal spots on the forewing above, rounded tails, and yellow spots on the neck, not joined into stripes (inset to Fig. 3). Although it is impossible to be certain that "New York", as stated below the drawing, is indeed the true locality where this specimen was captured (Clench and Miller 1980), P. cresphontes has been reported from northern states such as New York prior to 1900s (Dwight 1882, Holland 1898), even if it was quite rare. Nevertheless, "New York" was the first of the three specific localities mentioned by Cramer in the H. cresphontes description. Also, the male specimen illustrated is heavily patterned. Such specimens are less common in collections and may be easily recognizable if this syntype is eventually found. For these reasons, this male specimen, illustrated by Lambertz in Volume 2, plate 134, figure 3 and stated to be from "New York" and reproduced in Cramer (1777) plate CLXVI B, with a complete row of 7 submarginal spots on the forewing, small oval dark-brown spot in the anterobasal quadrant of the yellow spot in forewing cell $\mathrm{R}_{5}-$ $M_{1}$, and small yellow spots on the head above and behind the eyes and on the patagia, 

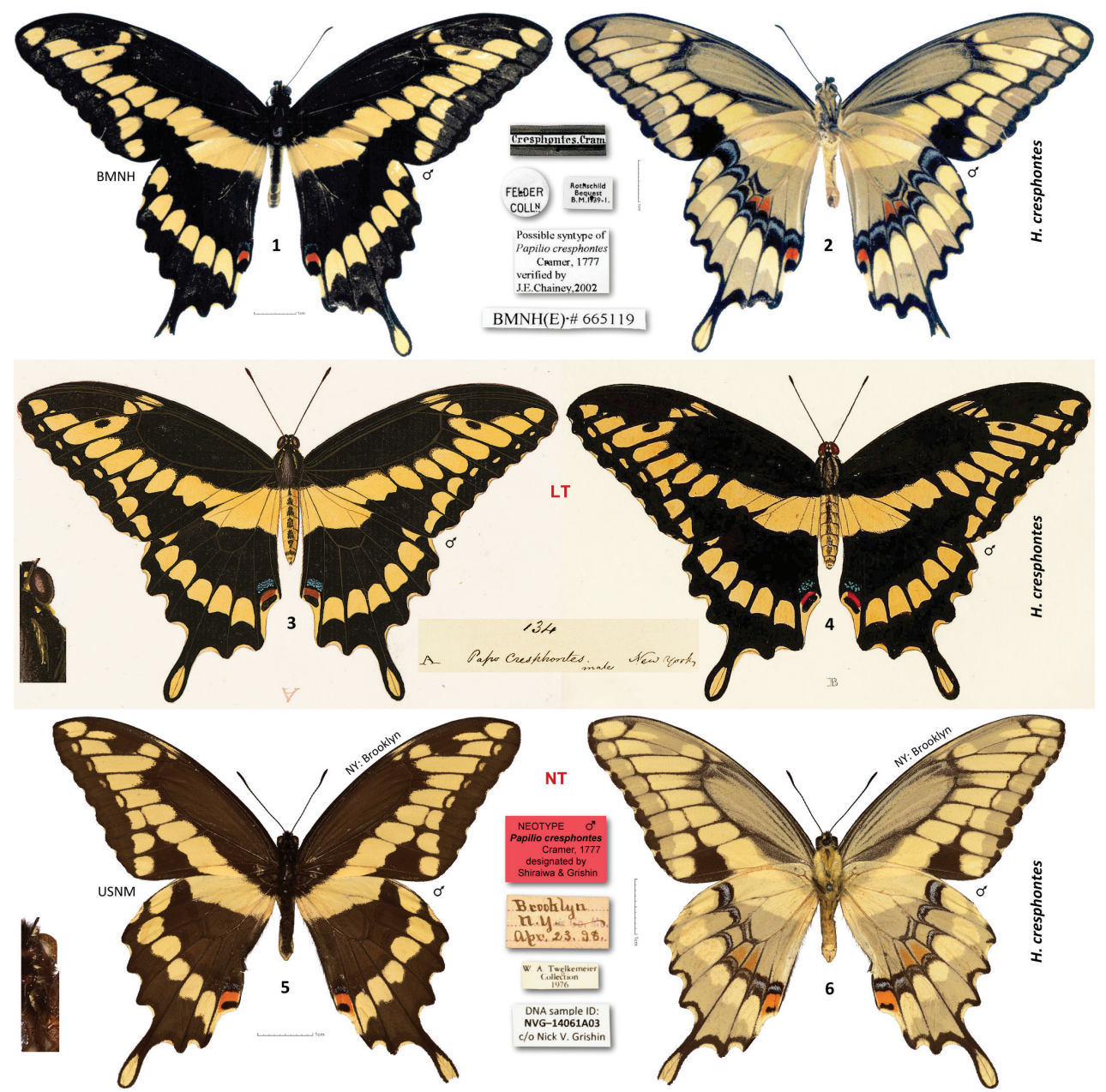

Figures I-6. Heraclides cresphontes type specimens and illustrations. I-2 possible paralectotype [BMNH] 3 Lambertz original illustration of the lectotype designated herein, specimen apparently lost 4 published engraving of the lectotype (Cramer, 1777) 5-6 neotype $\widehat{\sigma}$ designated herein. Data in text and Supplementary Table 1. Dorsal/ventral surfaces are in odd/even-numbered figures, except 4, which shows dorsal. Labels are shown between the images of the same specimen, 3-fold magnified segment of head, neck and thorax is on the left and a 6-fold magnified dorsoposterior view of abdomen is on the right. 1 $\mathrm{cm}$ scale bars for specimens and labels are shown. Images 1-2 are by Gerardo Lamas, copyright Trustees of the Natural History Museum, London; used with permission.

not connected to yellow lines on tegulae, is hereby designated the lectotype of Papilio cresphontes Cramer, 1777 . The identity of the lectotype is in agreement with the usage of this name since it was proposed. The lectotype is designated to ensure nomenclatural stability due to polytypic type series including two species, and to clarify the type locality, which becomes USA: New York. We were not able to locate the lectotype and consider it to be lost. 


\section{Lectotype designation for Papilio thoas Linnaeus, 1771}

The above lectotype designation resolves the problem between $H$. cresphontes and $H$. melonius, both of which were in the $H$. cresphontes type series; and for the interest of stability secures traditional usage of these names: $H$. cresphontes for eastern North America populations, and $H$. melonius, in accord with its original description (Rothschild and Jordan 1906), for Jamaica. Additionally, if a $H$. cresphontes syntype is found, unless there is strong evidence that it is the specimen pictured on the Cramer plate CLXVI B (and the original Lambertz illustration shows excellent details), it is not a name bearing type. The next problem is that the $H$. thoas type series included at least one $H$. cresphontes specimen, the one from Daubenton (1765: 69), discussed above. Due to the inclusion of this specimen in the original description by Linnaeus (1771) and a type locality originally listed as "Guadalupa, Surinamo", a potential for nomenclatural instability exists. Rothschild and Jordan (1906) considered the Daubenton illustration, which locality "Guadalupa" refers to, to be $H$. cresphontes. Honey and Scoble (2001) concurred with this conclusion, stating: "the type locality of thoas can, with good reason, be restricted to Surinam", but they didn't designate the lectotype. Linnaeus (1771) listed specimen(s) illustrated by Drury (1770: pl. 22, figs 1,2) first, before listing other references. The Drury illustrations are excellent and agree with the subsequent usage of the name, and the locality is stated in the text: "Surinam" (Drury 1770: 45). To stabilize nomenclature and clarify the type locality, we designate a specimen with 4 submarginal yellow spots, a small spot near the apex of the dorsal forewing and a yellow spot at the posterodistal end of the forewing discal cell, illustrated in Fig. 1 on the Drury (1770) Plate 22 as the lectotype of Papilio thoas Linnaeus, 1771. The whereabouts of the lectotype are unknown, but the Drury illustration is of sufficient quality to confidently identify the species and see that the lectotype is in agreement with the prior and current usage of the name. The type locality of $H$. thoas becomes Suriname.

\section{Neotype designation for Papilio cresphontes Cramer, 1777}

The two lectotypes designated above unambiguously distinguish $H$. cresphontes, an eastern US species, from $H$. melonius and $H$. thoas. However, with our finding that $H$. cresphontes is a complex of two sister species, the lectotype, which is apparently lost, may not be sufficient to define the taxon from just a single illustration. While most specimens of the southwestern species differ from the eastern $P$. cresphontes in neck and wing patterns, its diagnostic characters are found in genitalia and DNA, and thus cannot be confirmed from the illustration alone. Therefore, we proceed with the designation of the neotype in accord with ICZN Article 75.3 (ICZN 1999). The exceptional need for the $H$. cresphontes neotype arises to unambiguously distinguish it from the southwestern species, and have an actual name-bearing type specimen for future DNA research. A male specimen in the National Museum of Natural History, Smithsonian 
Institution, Washington, DC (USNM) mounted ventral side up, illustrated in Figs 5-6, and bearing the following three rectangular labels: faded to wheat color, handwritten - || Brooklyn | N. Y. - |Apr. 23. 98. ||; white printed - || W. A. Twelkemeier | Collection | 1976 ||; white printed - || DNA sample ID: | NVG-14061A03 | c/o Nick V. Grishin || is hereby designated as the neotype of Papilio cresphontes Cramer, 1777. The red printed label - || NEOTYPE Ō | Papilio cresphontes | Cramer, 1777 | designated by $\mid$ Shiraiwa $\&$ Grishin || will be added to the neotype upon publication of this study. Length of the neotype forewing is $48 \mathrm{~mm}$, and this specimen can be recognized by a unique pattern of minor damage along the anal margin of left hindwing basad of the blue crescent, and missing tip of the tail on right hindwing (Fig. 5). Neotype is an old specimen, collected in 1898, although over a century more recent than the Cramer's type, it may still better represent the fauna of New York prior to major industrial developments. According to ICZN Code Art.76.3., the type locality of H. cresphontes becomes USA: New York, Brooklyn.

This neotype designation satisfies all seven provisions of the ICZN code (Art. 75.3.1.-7.) as follows. The neotype is designated to clarify the attribution of the name $H$. cresphontes to the eastern (and not southwestern) species in accord with traditional usage of the name and the type locality of the lectotype (Art. 75.3.1.) The characters to differentiate $H$. cresphontes from the southwestern species are listed in the first two paragraphs of the Results section and additionally in the Diagnosis section of the description below (Art. 75.3.2.). The neotype and its labels are shown in Figs 5-6 (Art. 75.3.3.). The steps taken to trace the lectotype are described above (Art. 75.3.4.). Neotype agrees with the original description and is rather similar to the lectotype illustration: it is of a broadly patterned yellow spring form, with all 7 submarginal yellow spots on the forewing expressed, and with small yellow spots on head, patagia, and tegulae (Art. 75.3.5.). The lectotype was stated to be from "New York", and the neotype was collected in Brooklyn, New York, closely matching the locality of the lectotype (Art. 75.3.6.). The neotype is in the National Museum of Natural History, Smithsonian Institution, Washington, DC (USNM) (Art. 75.3.7.). Facies, DNA barcode ID tag (GenBank Accession KP173859), and locality of the neotype unambiguously attribute the name $H$. cresphontes to the eastern species, leaving the southwestern species for further analysis.

\section{Analysis of names proposed for $H$. cresphontes}

Eight names have been considered synonyms of $H$. cresphontes by Lamas (2004) and Pelham (2008). Out of these, Heraclides oxilus Hübner, [1819] is an objective junior synonym, because it was proposed as a replacement name for $H$. cresphontes, erroneously considered to be preoccupied; Papilio cresphontes var. maxwelli Franck, 1919 and Papilio cresphontes pennsylvanicus F. Chermock \& R. Chermock, 1945 are subjective junior synonyms, based on specimens from USA: Florida: Pinellas County, St. Petersburg (Franck 1919b) and USA: Pennsylvania, Centre County, State College, respectively. 
We consider maxwelli to be an available name according to ICZN Code Art. 45.6.4., because (1) it was published before 1961, (2) the author used the terms "var." and "variety", and (3) the publication does not unambiguously reveal that the name is infrasubspecific. The entire description text is very short, cited here: "The triangular spot near the apex of the primaries is entirely filled out with sulphur yellow, giving the specimen a striking tropical appearance. This variety is named after my esteemed friend Mrs. J. B. Maxwell, of Faribault, Minn." (Franck 1919a). The maxwelli holotype ("the specimen") is a strongly patterned with yellow, mostly likely spring brood individual, probably somewhat aberrant. It is eastern $H$. cresphontes by facies, and is pictured in Warren et al. (2014). We agree with Lamas (2004) and Pelham (2008) in treating the name as a synonym of $H$. cresphontes, because we do not see consistent differences between Florida populations of $H$. cresphontes and those from northeastern US near the $H$. cresphontes type locality.

The name pennsylvanicus was proposed as a subspecies (Chermock and Chermock 1945). The type series specimens are characterized by weaker developed dark pattern on ventral side of wings, suggesting that specimens from the northeastern parts of the range may be weaker patterned in black. Facies of the H.c. pennsylvanicus holotype and facies and DNA barcodes of two paratypes from the same locality are of $H$. cresphontes and not of the southwestern species. However, paler specimens are found throughout the range of $H$. cresphontes, not only in the northeast, and are occasional even in the southwestern $H$. cresphontes-like species. $H$. cresphontes neotype is also from northwest and is weaker patterned with black below (Fig. 6). Therefore, we concur with Pelham (2008) that it is best to treat pennsylvanicus as a subjective junior synonym of $H$. cresphontes rather than a meaningful subspecies.

The remaining six names are infrasubspecific according to the Articles 45.5. \& 45.6. of the ICZN Code, in agreement with Pelham (2008) and therefore are unavailable. Three were proposed explicitly for aberrations: ab. (nov.) lurida Schultz, 1908; ab. luxuriosa Reiff, 1911; and ab. intacta Strand, 1918, and thus are infrasubspecific according to Art. 45.6.2. For the final two names, both published before 1961: tr. f. forsythae Gunder, 1933; and forma melanurus Hoffmann, 1940, "the content of the work unambiguously reveals that the name was proposed for an infrasubspecific entity" (ICZN 1999: Art. 45.6.4.). The first one was based on specimens from USA: Florida and the facies of the holotype agree with $H$. cresphontes.

However, the second one, Papilio cresphontes forma melanurus, is from Mexico: Guerrero, and the facies of the holotype imply that it is the southwestern species, not $H$. cresphontes. Although its name as originally proposed contains the word "forma", the text of the description (Hoffmann 1940) is clear about it being a form with dark tails inside populations of typical $H$. cresphontes with yellow-spotted tails: "It differs from cresphontes cresphontes Cramer by its entirely black tails that lack the typical yellow spot. The form is found together with typical cresphontes with some frequency in the Balsas River basin and the mountains of the State of Guerrero" (translated from Spanish original)—i.e., "La forma se encuentra junto con cresphontes typicus con cierta frecuencia" unambiguously implies that the name is infrasubspecific: black- 
tailed $H$. cresphontes that flies together with typical $H$. cresphontes in Guerrero is not its subspecies, but a form. From the description, it is equally unambiguous that Hoffmann considered populations in Mexico: Guerrero to be typical $H$. cresphontes. The name melanurus was not adapted for a subspecies since it was proposed. Therefore, the southwestern $H$. cresphontes-like species does not have a name and is named herein.

\section{Heraclides rumiko Shiraiwa \& Grishin, sp. $\mathbf{n}$.}

http://zoobank.org/F876D822-AB4D-44DF-AB7C-02C5131B91FA

Figs $7-10,11 \mathrm{a}-\mathrm{d}, 12 \mathrm{a}-\mathrm{i}, 12 \mathrm{E}$ part, 13 part, 14 part, 15 part, 16 part, 17 part, 18 part, $19 \mathrm{a}-\mathrm{x}, 20 \mathrm{a}-\mathrm{r}, 21 \mathrm{a}-\mathrm{n}, 22 \mathrm{a}-\mathrm{j}, 23 \mathrm{a}-\mathrm{l}$

Description. Male ( $\mathrm{n}=95$, Figs 7-8, 11a, 13 part) - holotype forewing length $=50$ $\mathrm{mm}$. Size on average smaller (mean forewing length $54 \mathrm{~mm}$, maximum observed 58 $\mathrm{mm}$ ) than $H$. cresphontes. Wings typically narrower, less scalloped, and wing shape less variable than in $H$. cresphontes, hindwing tail longer and narrower, weakly spoonshaped. Ground color black to dark chocolate-brown. Dorsal forewing: Two maizeyellow bands: a central band of 9 spots from apex to basal third at inner margin in all cells from $R_{3}-R_{4}$ to $1 A$; and a sub-marginal band of 3 to 7 spots in cells from $R_{4}-R_{5}$ to $\mathrm{CuA}_{2}-1 \mathrm{~A}$, absent or vestigial in most specimens anteriad of three cells between $\mathrm{M}_{3}$ and $1 \mathrm{~A}$ veins. Several smaller maize-yellow spots near costa at the end of discal cell. Background-colored dark oval spot of variable size inside or at the anterior edge of the yellow central band spot in cell $\mathrm{R}_{5}-\mathrm{M}_{1}$, sometimes dividing the yellow spot into two. Marginal pale spots at dips between veins small or almost absent. Dorsal hindwing: Two maize-yellow bands extending from forewing: undivided into spots central band in wing basal third from costa to inner margin, with small tooth-like protrusions distad along veins $R s$ and $M_{1}$; and sub-marginal band of 7 spots in cells from $S_{c}+R_{1}-R s$ to $\mathrm{CuA}_{2}-1 \mathrm{~A}+2 \mathrm{~A}$, the tornal spots up to margin. Maroon-red to orange-red eyespot near tornus with blue crescent above. Center of the tail tip yellow. Ventral forewing: Yellow color paler; wider yellow central band weakly divided into spots from forewing costa to inner margin; submarginal band of 8 or 9 (spot near tornus may be divided into two) spots larger than on dorsal side in cells between veins $\mathrm{R}_{3}$ and $1 \mathrm{~A}$. Marginal pale spots at dips between veins larger than above. Discal cell yellow, overscaled with dark and with 5 variously developed dark longitudinal streaks. Ventral hindwing: Largely maize-yellow, a dark-brown rather straight discal band from costa through the end of discal cell to tornus with blue crescents inside in each cell and orangered tornal spot distal to blue crescent. Distal end of discal cell with black (in some specimens blue) lines, often fused with the median band. Cells $M_{2}-M_{3}$ and $M_{3}-C u A_{1}$ orange-red at the base; few or no orange-red scales at the base of $M_{1}-M_{2}$ cell. Margin bordered black, with yellow edges along concavities. Dark-brown rays along veins between discal and marginal dark bands. Tail tip with yellow spot in the middle. Head and body: Antennae dark-brown, segments ringed with yellow beneath. Head and thorax dark-brown dorsally and yellow ventrally. Two longitudinal yellow stripes on 


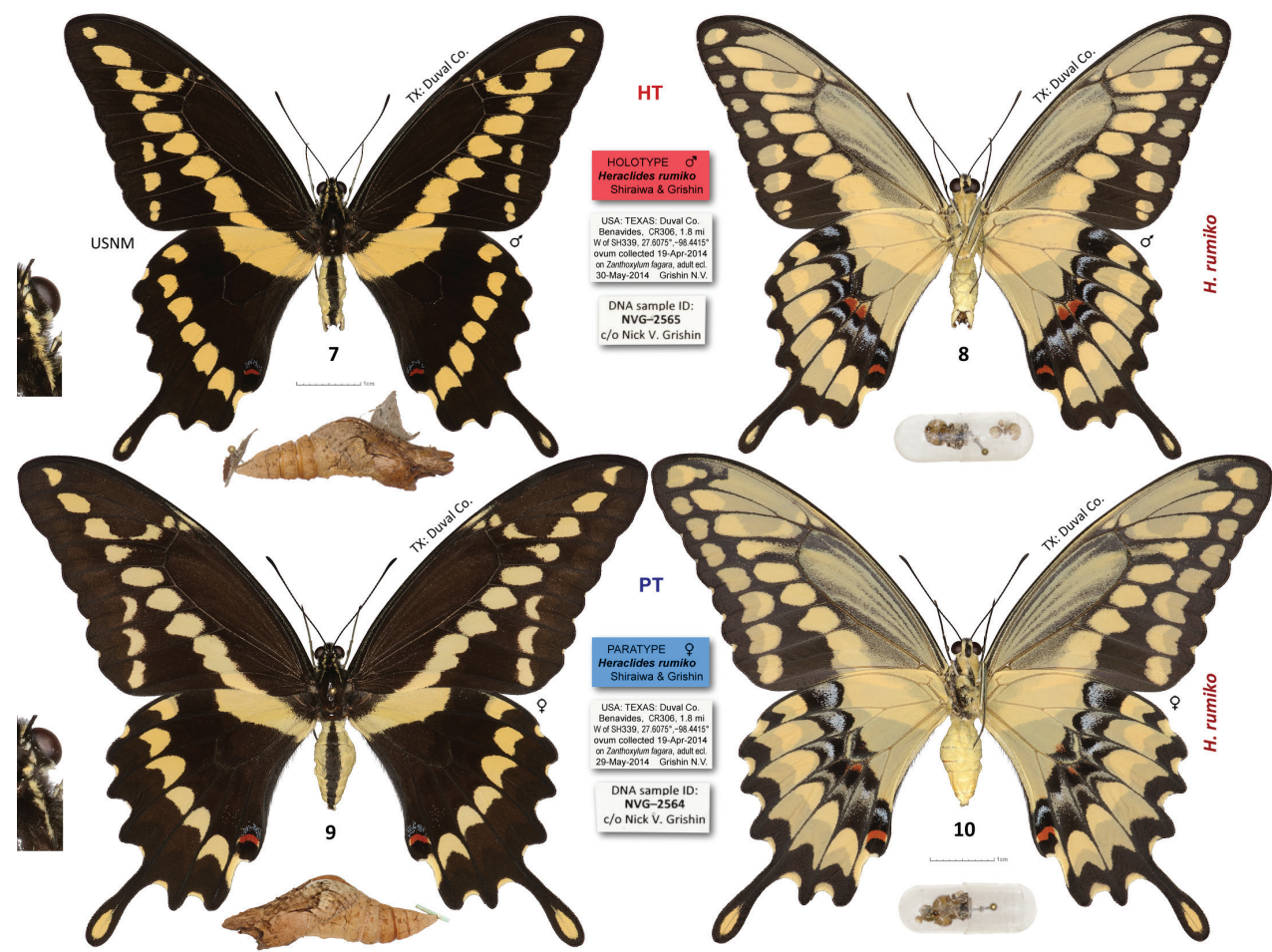

Figures 7-10. Heraclides rumiko type specimens: 7-8 holotype $\widehat{9} \mathbf{9 - 1 0}$ paratype $\odot$ NVG-2564, data in text and Supplementary Table 1. Dorsal/ventral surfaces are in odd/even-numbered figures. Labels are shown between the images of the same specimen, exuvia and head capsules in a gelatin capsule are below, and 3-fold magnified segment of head, neck and thorax is on the left. All images are to scale (including labels), except the magnified insets.

head, patagia and tegulae forming two continuous yellow lines from head to thorax (Fig 11a), only rarely and weakly separated into spots. Abdomen yellow, with a black dorsal stripe fading posteriad in many specimens. Male genitalia ( $\mathrm{n}=34$; Fig. 11a-d, 14 part): Pseuduncus shaped as a tooth like, pointed projection flattened at the tip not extending posteriad beyond uncus, thus leaving a gap between the last tergum and valvae. In lateral view, pseuduncus dorsally flat but ventrally convex towards the tip. Uncus more slender than in H. cresphontes, divided into two curved horn-like arms; each arm directed posterodorsad, curved laterad initially and then strongly mediad, narrowing to a point. Brachium arms from the base of uncus ventrad, narrow, shorter than uncus, directed posteroventrad and mediad, differently from uncus in dorsoventral projection. Both uncus and brachium visible in dorsal view (Fig. 11c). In H. cresphontes brachium mostly covered by uncus (Fig. 11C). Valva somewhat square in shape, broadly rounded at the angles. Harpe oval, without long projections and spikes, finely dentate ventrad in posterior half, with apex curved inward. Distal end of harpe very close to the edge of valva, closer than in $H$. cresphontes, and valva projects distad from the denticulate edge of harpe less than in $H$. cresphontes, costa of valva usu- 

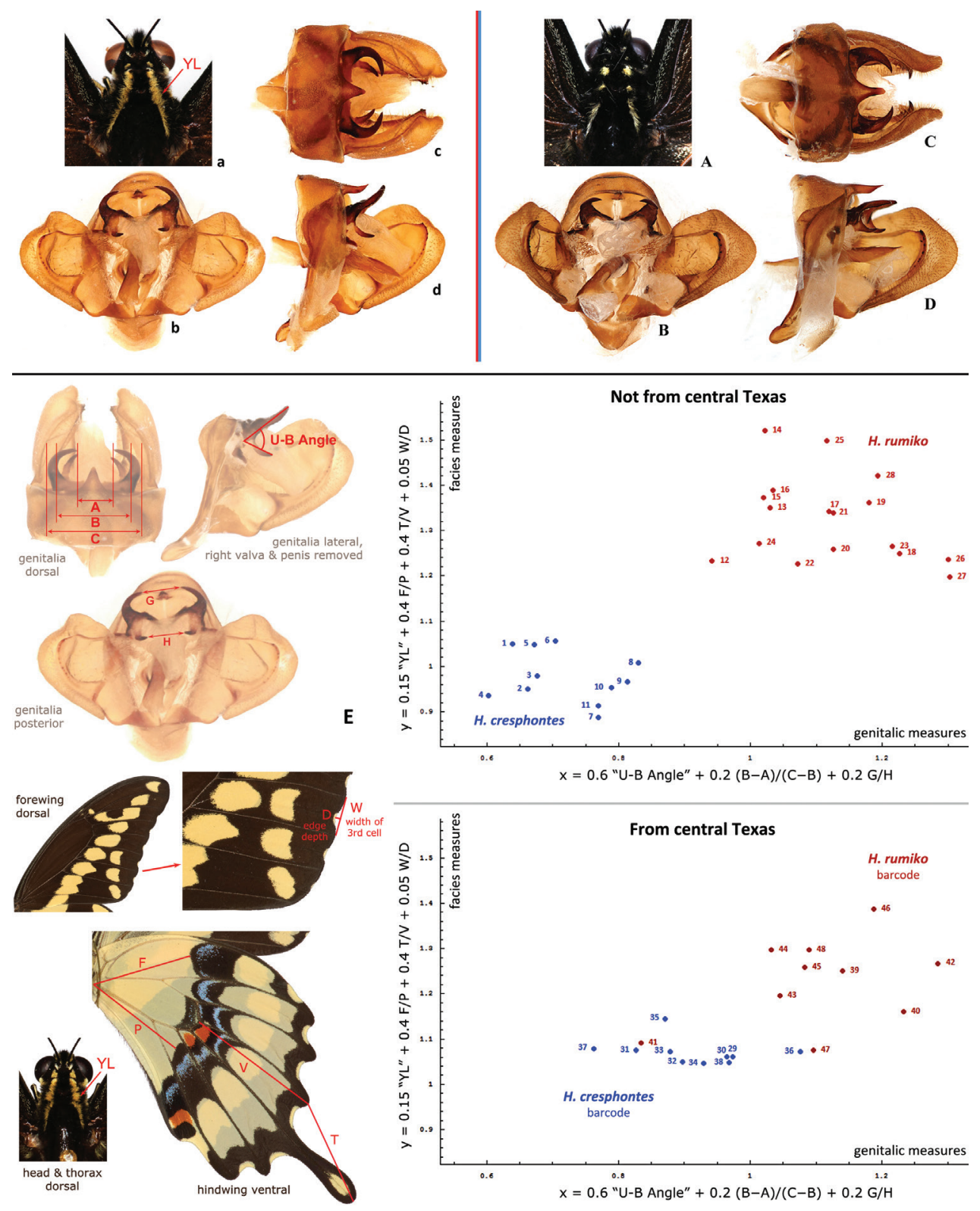

ally broader than in $H$. cresphontes. Aedeagus as long as the valva, straight and stout, no cornuti. Juxta U-shaped, gracile and smooth. Saccus short, barely protruding anteriad beyond vinculum.

Female ( $\mathrm{n}=28$, Figs 9-10): Similar to male but larger, with broader wings, ground color paler, yellow bands typically narrower and paler: cream-yellow on forewing and somewhat yellower on hindwing. Female genitalia $(\mathrm{n}=11$, Fig. 12a-i): Lamella 
Figure II. Neck pattern, male genitalia, and morphometrics. a-d H. rumiko, paratype, Mexico: Baja California Sur: Buena Vista, 1-Oct-1981, leg. D. Faulkner \& F. Andrews, genitalia KS017 [SDMC] AD H. cresphontes, USA: Georgia: Clark Co. July 2009, genitalia KS009 E Morphometric measurements performed on genitalia and facies and plotted in two dimensions. Horizontal axis is a weighted average of the three genitalic measures: $0.6^{*}$ "U-B Angle" $+0.2^{*}(\mathrm{~B}-\mathrm{A}) /(\mathrm{C}-\mathrm{B})+0.2^{*} \mathrm{G} / \mathrm{H}$. "U-B Angle" is measured in radians. Vertical axis is a weighted average of the four facies measures: $0.15^{* \prime} \mathrm{YL}$ " $+0.4^{*} \mathrm{~F} / \mathrm{P}+0.4^{*} \mathrm{~T} / \mathrm{V}$ $+0.05 \mathrm{~W} / \mathrm{D}$, where "YL" is equal to 0 or 1 , if yellow line on the neck is separated into spots or continuous, respectively. Measured distances are indicated on the illustrations. Each of the two (genitalic and facies) linear combinations of measures completely segregates $H$. rumiko (red points) from $H$. cresphontes (blue points) specimens (not from central Texas) with a hiatus. Even a single measure "U-B Angle" identifies all specimens correctly, except \#12, which has a brachium strongly curved dorsad. Specimen localities: $H$. cresphontes: 1. GA: Clark Co.; 2. NY: Niagra Co., Lockport; 3. NC: Carteret Co.; 4. IN: Kosciusko Co., Silver Lake; 5. WI: Sauk Co., Sauk City; 6. LA: St. John Pa., Edgard; 7. AR: Osceola; 8. OK: Marshall Co., Lake Texoma; 9. FL: Okeechobee Co., Fort Drum; 10. OH: Montgomery Co., Dayton; 11. PA: York Co., Pinchot State Park. H. rumiko: 12. AZ: Maricopa Co., North Phoenix; 13. AZ: Santa Cruz Co., Sycamore Canyon; 14. CA: Imperial Co.; 15. MX: Veracruz, Fortin de las Flores; 16. MX: Oaxaca, Yangul; 17. Costa Rica: Puntarenas, San Antonio; 18. MX: Tamaulipas, Gomez Farias; 19. MX: Colima, Colima; 20. MX: Sonora; 21. MX: Yukatan, Merida; 22. MX: Morelos, Rancho Viejo; 23. MX: BCS, Buena Vista; 24. MX: Jalisco, Ajajic; 25. CA: San Diego Co., La Jolla; 26. MX: Quintana Roo, nr. X-Can; 27. TX: Val Verde Co., Del Rio; 28. CA: San Diego Co., Pauma Valley. Central Texas specimens are from Bexar (33-38, 42-48), Williamson (39-41), Travis (31, 32), Bastrop (30), and Brazos (29) Counties. Voucher codes for these specimens are: 29. NVG-2236; 30. -2299; 31. -2300; 32. -2174; 33. -2192; 34. -2196; 35. -2205; 36. -2209; 37. -2210; 38. -2216; 39. -2301; 40. -2225; 41. -2229; 42. -2191; 43. -2197 ; 44. -2204 ; 45. -2208 ; 46. -2211 ; 47. -2215 ; 48. -2218. Species (color on the plot) is assigned to central Texas specimens by COI barcode. See Supplementary Table 1 for more data. Specimens 36 and 41 are apparent hybrids or the results of introgression.

postvaginalis tongue-shaped, ventrally convex smooth plate somewhat longer than wide, with rounded or slightly concave posterior margin, variable in width and length, lamella antevaginalis narrow, poorly sclerotized, laterally extending into narrow peripheral vestibular plates surrounding lamella postvaginalis on the sides up to its middle. Inner edge of each plate with short, tooth-like projection in some specimens (Fig. 12e). Antrum with two weakly sclerotized small plates along sides. Ductus bursae short, not longer than sterigma. Corpus bursae with a long longitudinal signum on ventral side.

Barcode sequence of the holotype. Genbank accession KP173713, 658 base pairs: AACATTATATTTTATTTTTGGAATTTGAGCAAGAATACTAGGAACTTCTCTTAGTTTACTAATTCGTACTGAATTAGGCACCCCCGGCTCATTAATTGGAGATGATCAAATTTATAATACTATTGTTACAGCTCATGCTTTTATTATAATTTTTTTTATAGTTATACCTATTATAATTGGAGGATTTGGAAATTGATTAATTCCATTAATATTAGGAGCCCCTGATATAGCTTTTCCTCGTATAAATAATATAAGATTTTGACTTTTACCCCСTTCTCTAACTCTCCTAATTTCAAGAATAATTGTAGAAAATGGGGCAGGAACTGGATGAACTGTTTACCCTCCTCTTTCCTCTAATATTGCCCATGGAAGAAGATCAGTAGATTTAGTTATCTTTTCTTTACATTTAGCTG- 

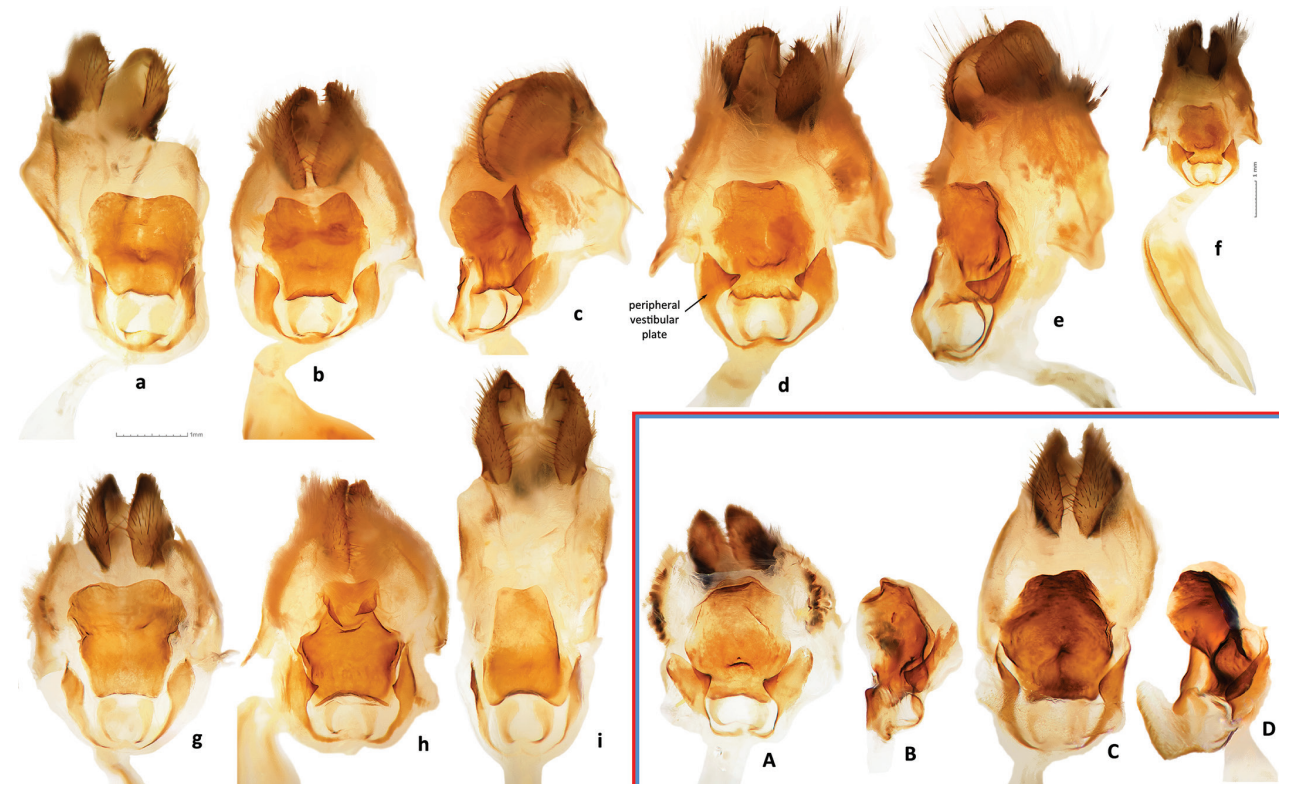

Figure 12. Female genitalia. a-i $H$. rumiko paratypes [TAMU]: a USA: TX: Cameron Co., Las Palomas WMA, Tucker Unit, 24-Oct-2001, leg. J. \& F. Preston, DNA voucher NVG-2238, genitalia NVG140320-79 b, c USA: TX: Hidalgo Co., Santa Ana National Wildlife Refuge, 13-Oct-1968, leg. R. O. Kendall \& C. A. Kendall, NVG-2163 | NVG140320-04 d-f USA: TX: Cameron Co., World Wildlife Management Area nr. Santa Maria, 14-Nov-1971, leg. R. O. Kendall \& C. A. Kendall, NVG-2195 | NVG140320-36 g Honduras: Escuela Agrícola Panamericana, 30 km SE Tegucigalpa, 1-May-1985, leg. Vascones, NVG-2221 | NVG140320-62 h Mexico: Durango: Tlahualilo, 20-Aug-1935, leg. C. S. Rude, NVG-2230 | NVG140320-71; i Mexico: Tamaulipas: Cd. Monte, Los Arcos Ct., 8-May-1978, leg. R. O. Kendall \& C. A. Kendall, NVG-2185 | NVG140320-26 A-D H. cresphontes, USA: MO: A, B Phelps Co., Mark Twain National Forest, DeWitt Pond, N37.8367 W91.9385, 25-May-2006, J. C. Abbott, NVG-2293 | NVG140403-21 [TMMC] C, D Montgomery Co., NVG-2242 | NVG14032083 [TAMU]. Ventrolateral view is shown in $\mathbf{c}, \mathbf{e}, \mathbf{B}, \mathbf{D}$ (e is left-right inverted), others are in ventral view. All images are to scale shown under $\mathbf{a}$, except $\mathbf{f}$, which is half the size with scale shown to the right.

GTATTTCCTCAATTCTTGGAGCAATTAATTTTATTACTACAATTATTAATATACGAATTAATAGAATATCTTTTGATCAAATACCTTTATTTGTTTGAGCCGTAGGAATTACAGCTTTATTATTACTTTTATCTTTACCTGTTTTAGCAGGAGCTATTACTATACTTTTAACTGATCGAAATTTAAATACTTCATTTTTTGACCCTGCTGGAGGAGGAGATCCAATTTTATACCAACATTTATTT

In addition to the holotype, barcodes and ID tags were obtained for 110 paratypes: 93 full-length barcodes (658 to $664 \mathrm{bp}$ ), 3 partial barcodes ( $443 \mathrm{bp}$ ) and 14 ID tags (64 bp), see Suppl. material 1, GenBank accessions: KP173714-KP173823. Full length barcodes of paratypes revealed ten haplotypes differing from each other by just 1 to 3 base pairs (less than $0.5 \%$, Fig. 17). The haplotype of the holotype was most frequently observed (67 sequences). 
Type material. Holotype: $\delta$, has the following three rectangular labels: white printed - || USA: TEXAS: Duval Co. | Benavides, CR306, $1.8 \mathrm{mi} \mid$ W of SH339, $27.6075^{\circ}-98.4415^{\circ}$ ovum collected 19-Apr-2014 | on Zanthoxylum fagara, adult ecl. | 30-May-2014 Grishin N.V. ||; white printed - || DNA sample ID: | NVG-2565 | c/o Nick V. Grishin \|; red printed - || HOLOTYPE $\widehat{~} \mid$ Heraclides rumiko Shiraiwa \& Grishin II. Pupal exuvia and larval head capsules are stored with the holotype. The holotype is illustrated in Figs 7-8, 19a-d, v, \& 23a-c, and the Genbank accession for its DNA COI barcode sequence is KP173713. Upon publication, the holotype will be deposited in the National Museum of Natural History, Smithsonian Institution, Washington, DC (USNM). Paratypes: $94 \hat{\jmath} \widehat{\partial}$ and 28 우. Of these, $1 \hat{\delta}$ and 2 우 9 with the same data as the holotype, eclosion dates 26-, 27-, 29-May-14; DNA vouchers NVG-2559, -2563, -2564. USA: Texas: 28 $\delta$ and 6 우 Duval Co., along SH339, 1-5 mi SW Benavides, 19-Apr-2014, leg. N. V. Grishin \& Q. Cong, DNA vouchers NVG-2335--2339, -2425--2453; Duval Co., SH359, 7.6 mi NE Benavides, $27^{\circ} 40.443^{\prime}-98^{\circ} 19.209^{\prime}$, ex larva, leg. N. V. Grishin, eclosed: 1 đond 1 q 16-Nov-2003, NVG-38, -2097; 1 § 25-Nov-2003, leg. N. V. Grishin, NVG-2095; 2 đô 3-Jun-2004, leg. N. V. Grishin, NVG-2098, -2099; Cameron Co., E of Brownsville, Palmetto Hill Rd., leg. N. V. Grishin: 1 đ 11-Nov-1996, NVG-2102; ex larva, 1 5-Dec-2007, NVG-2100; 1 \& Cameron Co., World Wildlife Management Area nr. Santa Maria, 14-Nov-1971, leg. R. O. Kendall \& C. A. Kendall, NVG-2195 | NVG140320-36 [TAMU]; 1 \& Cameron Co., Las Palomas WMA, Tucker Unit, 24Oct-2001, leg. J. \& F. Preston, NVG-2238 | NVG140320-79; 1 đ Cameron Co., Brownsville, 1-Apr-1981, leg. C. Bordelon, NVG-2223 | NVG140320-64 [TAMU]; Hidalgo Co., Mission, 10th St. at irrigation ditch [TAMU]: 1 के 2-Sep-1972, leg. W. W. McGuire, NVG-2164 | NVG140320-05; 1 ठ 1 \& 8-Sep-1972, leg. R. O. Kendall

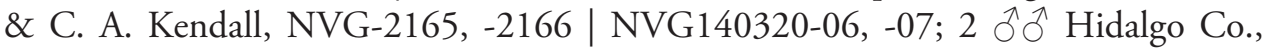
McAllen [TAMU]: 9-Oct-1973, leg. W. W. McGuire, NVG-2168 | NVG140320-09 [TAMU]; Valencia Motel, ex larva 21-Oct-1972, larval foodplant Ptelea trifoliata, leg. R. O. Kendall \& C. A. Kendall, NVG-2167 | NVG140320-08 [TAMU]; 1 i Hidalgo Co., Santa Ana National Wildlife Refuge, near Alamo, 13-Oct-1968, leg. R. O. Kendall \& C. A. Kendall, NVG-2163 | NVG140320-04 [TAMU]; 1 ○े San Patricio Co., SH 77 ca. 7 mi NNE of Sinton, Welder Wildlife Foundation, 10-Aug-1968, leg. R. O. Kendall \& C. A. Kendall, NVG-2173 | NVG140320-14 [TAMU]; 1 + San Patricio Co., 12.5 km NE Sinton @ SH 77, Welder Wildlife Foundation, 28.113, -97.418, 1-3-Jul-2002, J. C. Abbott \& Field Entomology Class, NVG-2302 | NVG140403-30 [TMMC]; 1 ○े Refugio Co., US Hwy 77 Mission River SW of Refugio, ex larva 17-Nov-1963, larval foodplant Zanthoxylum fagara, leg. R. O. Kendall \& C. A. Kendall, NVG-2171 | NVG140320-12 [TAMU]; 1 ô Brazos Co., College Station, Riley Estate, 30.58849, -96.25366, 14-15-May-2011, leg. M. L. Riley, NVG2243 | NVG140320-84 [Ed Riley]; 1 đ La Salle Co., 10.1 mi NW Artesia Wells, Chaparral Wildlife Management Area, 11-15-Jun-2001, J. C. Abbott \& Field Entomology Class, NVG-2298 | NVG140403-26 [TMMC]; 1 đ Kinney Co., 7 mi along railroad W of Spofford, 8-Oct-1966, leg. R. O. Kendall \& C. A. Kendall, NVG-2169 

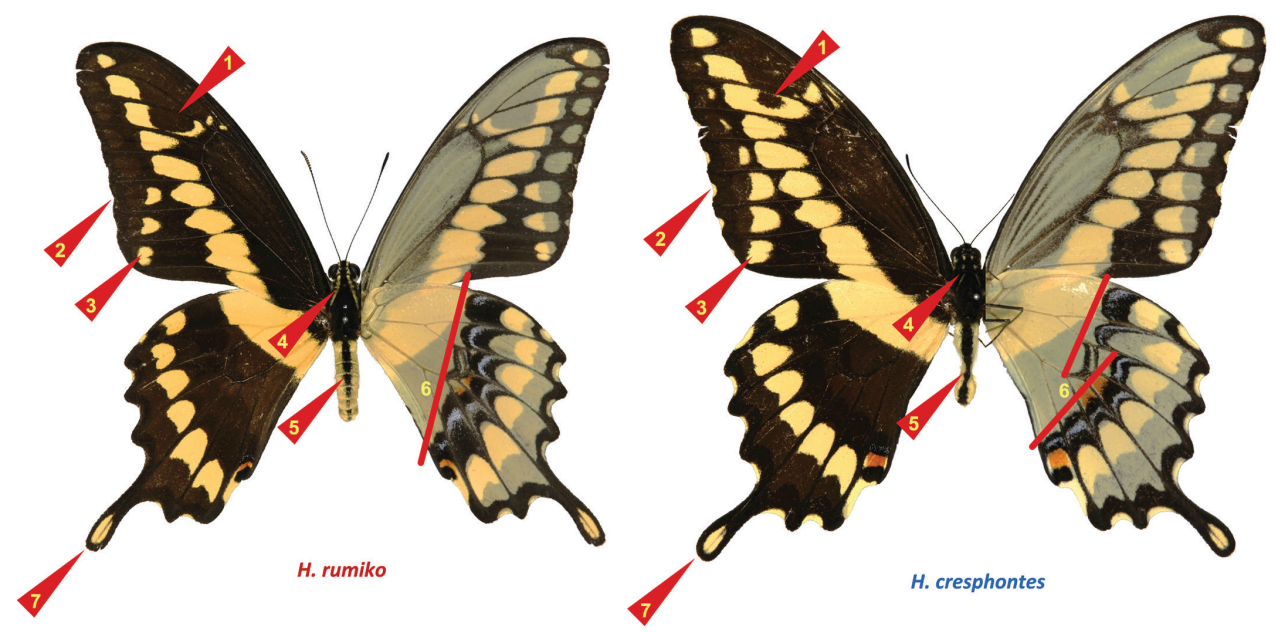

Figure 13. Facies differences between $H$. rumiko (left, r) H. cresphontes (right, c) indicated by red triangles and lines. These differences are as follows. I) Dark spot on forewing: (r) almost always large; (c) variable, but often weak and sometimes absent 2) Forewing margin: (r) often straight with smaller or absent marginal spots; (c) strongly scalloped with yellow marginal spots at dips between veins 3 ) Forewing submarginal yellow spots: (r) smaller rarely more than three; (c) frequently larger, more than three 4) Thorax with: (r) yellow line running from head through patagia to tegulae; (c) spots instead of the line, or just few yellow scales. 5) Abdomen: (r) usually with a fainter dark band; (c) often with solid dark band 6) Inner edge of black discal band on ventral hindwing: (r) mostly straight; (c) usually curved 7) Tail: (r) mostly narrow and relatively longer; (c) typically rounder and wide, shorter. H. rumiko is usually smaller than $H$. cresphontes, despite being a southern taxon. Due to significant seasonal and individual variation, none of these characters is fully reliable and exceptions exist. The head-neck-thorax line vs. spots (Fig. 11a, A) might be the strongest single character. A combination of characters should be used for reliable identification, e.g., the one shown in Fig. 11E. Many specimens in central Texas exhibit intermediate characters, atypical character combinations, and possible hybrids can be found (Fig. 11E).

| NVG140320-10 [TAMU]; Val Verde Co., Old US90 at Devils River W of Del Rio, ex larva larval foodplant Ptelea trifoliata, leg. R. O. Kendall \& C. A. Kendall [TAMU]: 1 o 16-Sep-1968, NVG-2176 | NVG140320-17; 1 ㅇ 8-Jun-1968 NVG-2175 | NVG140320-16; 1 ¡ Val Verde Co., Seminole Canyon State Historic Site, 26-May2007, 29.696, -101.336, leg. J. C. Abbott \& Field Entomology Class, NVG-2289 | NVG140403-17 [TMMC]; 1 त Terrel Co, 15 air mi S Sheffield, Oasis Ranch, Independence Cr., 30.467, -101.801, 595 m, 23-27-May-2007, J. C. Abbott \& Field Entomology Class, NVG-2290 | NVG140403-18 [TMMC]; 1 क TX: Tom Green Co., San Angelo, 13-Jul-1986, leg. P. Goroy, NVG-14081G05 [CSUC]; 1 Kerr Co., Kerrville, Riverside Nature Center, 10-Oct-1998, leg. W. F. Chamberlain, NVG2226 | NVG140320-67 [TAMU]; 1 § Kimble Co., Junction, 9-Oct-1966, leg. W. F. Chamberlain, NVG-2231 | NVG140320-72 [TAMU]; 1 q Van Zandt Co., $2.5 \mathrm{mi}$ W Van, IH20 rest stop, 28-Jul-1996, leg. N. V. Grishin, NVG-2092; Culberson Co., Guadalupe Mnts. National Park [CSUC], 1 đ̊ Choza Spr., 5000', 5-Jul-1986, leg. R. 


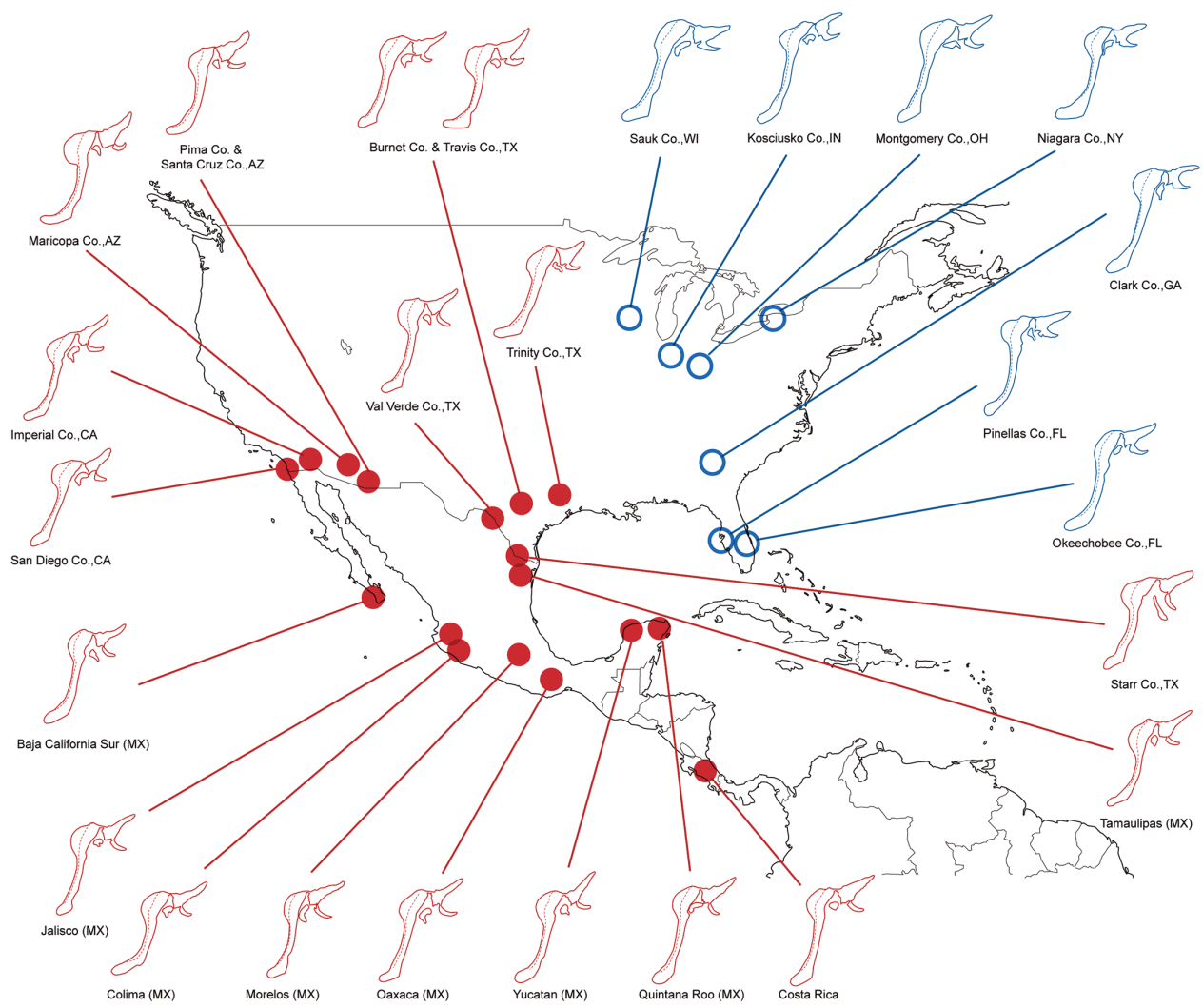

Figure 14. Variation in male genitalia. Left lateral view of genital ring (uncus, brachium, dorsolateral sclerite, tegumen, vinculum and saccus) is shown, valvae, aedeagus and last tergum with pseuduncus are removed. $H$. cresphontes and $H$. rumiko localities are shown in blue circles and red disks, respectively.

W. Holland \& S. J. Cary, NVG-14081G12; 1 ๆ Pine Spring Cmpgr., 5700', 20-Jun1986, leg. R. W. Holland, NVG-14081G11. USA: Colorado: 1 đ Logan Co., Sterling, 10-Jul-1970, leg. D. L. Munget, NVG-14081G09 [CSUC]. USA: New Mexico:

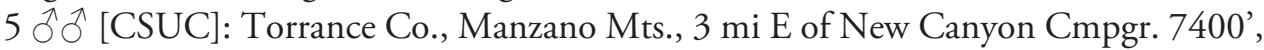
30-Jul-1968, leg. R. W. Holland, NVG-14081H02; Eddy Co., Last Chance Canyon, Sitting Bull Falls, 4600', 2-Sep-1986, leg. R. W. Holland \& S. J. Cary, NVG14081H09; Eddy Co., above Sitting Bull Falls, 4600', 20-Sep-1986, leg. R. W. Holland, NVG-14081H04; Eddy Co., Black River nr. Rattlesnake Spr., 3300', 19-Jul1986, leg. R. W. Holland, NVG-14081H01; Hidalgo Co., Peloncillo Mts., Guadalupe Canyon, SW slope, 4600', 8-Sep-1985, leg. S. J. Carry, NVG-14081H05. USA: Arizona: 1 ๙ Maricopa Co., North Phoenix, 10-Aug-1974, | KS032; 1 o Santa Cruz Co., Sycamore Canyon, 28-Aug-1977, leg. J. P. Brock, NVG-2109. USA: California: San Diego Co.: 1 O San Diego, ex ovum 23-Sep-2012, eclosed 6-Nov-2012, leg. K. Shiraiwa, NVG-2505; 1 ภ 1 † Pauma Valley, 17-Jul-2011 \& 25-Jun-2007, leg. K. Shiraiwa, NVG-2504, -2503; 1 đ 6762 Avenida Andorra, La Jolla, 2-Oct-1993, leg. 


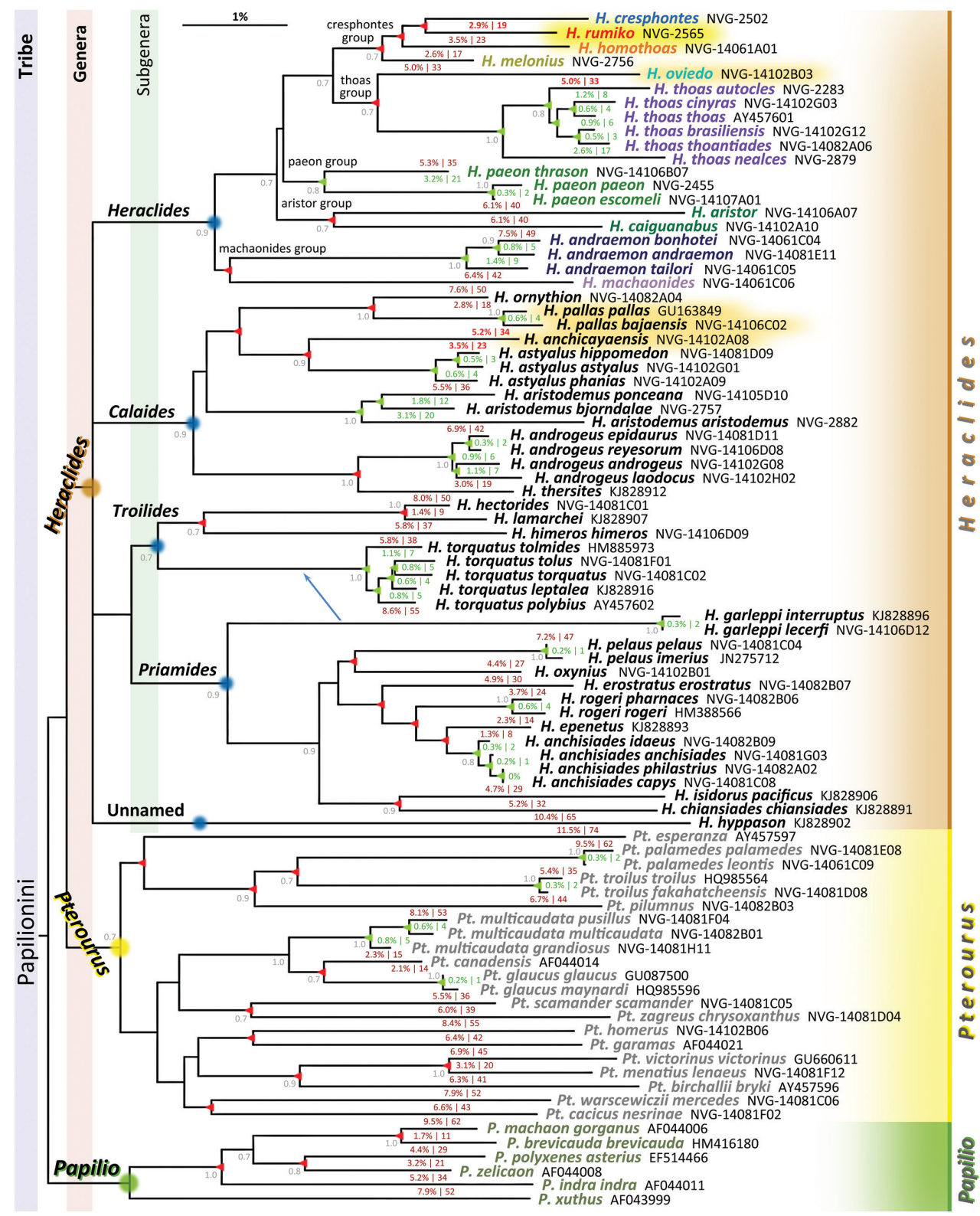

J. Stoddard, | KS016; 1 đ Imperial Co., ovum collected 17-Apr-1962, adult eclosed 13-Jul-1962, | KS029. Mexico: Baja California Sur: 1 \ La Paz, Hotel Posada, 27Sep-1970, leg R. W. Holland, NVG-14081G06 [CSUC]; 1 ㅇ 2 mi N of San Pedro, 500', 27-Sep-1970, leg. R. W. Holland, NVG-14081G04 [CSUC]; 3 ठิ $\widehat{~}$ Buena Vista [SDMC], 1-Oct-1981, leg. D. Faulkner \& F. Andrews, NVG-2572- 2574; 1 ô ibid, | KS017; 1 ð 48 mi S La Paz, 25-Aug-1982, leg. D. Faulkner \& J. Brown, 
Figure 15. COI DNA barcode distances within Papilionini in a form of a BioNJ (Dereeper et al. 2008) dendrogram built using fraction of nucleotide differences between sequences as distance. The scale bar corresponding to about $1 \%$ difference in sequences is shown above the tree. Sequences obtained in this work are with "NVG-" number (see Supplementary Table 1 for data), others are from GenBank (http:// genbank.gov/) and are labeled by accessions (letters and numbers, no dashes). Specimens with sequences from GenBank were not examined (except where a photograph was available from the BOLD database) and their identification follows original work, locality, and DNA barcode. Due to small number of phylogenetically informative positions, details of the tree topology especially closer to the root are not expected to be accurate (e.g., topology between subgenera of Heraclides remains unresolved and is shown as a quadfurcation) and the dendrogram is provided only to visualize the classification discussed in the text. Bootstrap values above 0.7 are shown by the nodes in gray font; "percent difference | number of differences" between the adjacent sequences in the dendrogram are shown between the branches. E.g., sequences of $H$. rumiko and $H$. homothoas differ by $3.5 \%$, which is 23 base pairs. Differences between species are colored red (to substantiate new name, new status, and new combination) and maroon, and differences between subspecies within species are colored green. Nodes leading to speciation events are marked with red triangles and nodes leading to diversification into subspecies are marked with green triangles. Three Neotropical genera of Papilionini, five subgenera of Heraclides (one unnamed) and five proposed species groups in the subgenus Heraclides are labeled. New species described in this study is highlighted yellow and taxa with proposed changes in taxonomic status or name combination are highlighted orange. Arrow indicates that $H$. garleppi belongs to subgenus Troilides by morphology, despite its COI barcode being more similar to Priamides.

NVG-2575. Mexico: Sonora: 1 đ 2 mi E San Carlos, 29-Jan-2003, leg. P. Opler, NVG-14081D10 [CSUC]; 1 + Sonora, 5mi S of Yecora, 11-Aug-1991, NVG-2110; 1 त Tepoca, 17-Sep-2010, | KS035 [SDMC]. Mexico: Sinaloa: 1 ๙ Panuco Rd. off Mx Hwy 40, 800', 29-Nov-3-Dec-2002, leg. Opler \& Buckner, NVG-14081E04 [CSUC]; 1 đ Mexico: Sinaloa, Mx Hwy 40, nr. Jct. of Mx 15, 400', 30-Aug-1967, leg. R. W. Holland, NVG-14081H08 [CSUC]; 1 ô Mazatlan, 29-Dec-1974, NVG2111. Mexico: Colima: 1 ô Colima, 5-Apr-1980, leg. P. Spade, | KS018 [SDMC]. Mexico: Durango: Tlahualilo, leg. C. S. Rude [TAMU]: 1 ๙ 19-Jul-1934, NVG2232 | NVG140320-73, 1 ㅇ 20-Aug-1935, NVG-2230 | NVG140320-71. Mexico: Coahuila: 1 J Jct Hwy $57 \& 53$ south of Moncloya, 14-Sep-1977, leg. R. O. Kendall \& C. A. Kendall, NVG-2180 | NVG140320-21 [TAMU]; 1 đ Cuatro Cienegas, 200 Ocampo St, Jul-1999, leg. A. Cohen, NVG-2284 | NVG140403-12 [TMMC]. Mexico: Nuevo Leon: 1 đ $28 \mathrm{~km}$ W Linares, 11-Apr-1979, leg. Schaffner \& Friedlander, NVG-2240 | NVG140320-81 [TAMU]; 1 ते Hwy 60, ca 50 km WSW Linares, 2-Mar-1974, leg. R. O. Kendall \& C. A. Kendall, NVG-2181 | NVG140320-22 [TAMU]; 1 đ̃ ca 21 km WSW Cola de Caballo, 4 May 1978, leg. R. O. Kendall \& C. A. Kendall, NVG-2182| NVG140320-23 [TAMU]. Mexico: Tamaulipas: $1 \curvearrowright$ Gomez Farias, 500m, 19-Jul-1973, leg. Wm. McGuire, | KS019 [SDMC]; 1 q Cd. Monte, Los Arcos Ct., 8-May-1978, leg. R. O. Kendall \& C. A. Kendall, NVG-2185 | NVG140320-26 [TAMU]. Mexico: San Luis Potosí: 1 đ̊ El Naranjo, 21-Feb-1976, leg. R. O. Kendall \& C. A. Kendall, NVG-2183 | NVG140320-24 [TAMU]; 1 え Hwy 70, 16 mi W Rioverde, 21-Feb-1980, R. O. Kendall \& C. A. Kendall, NVG- 

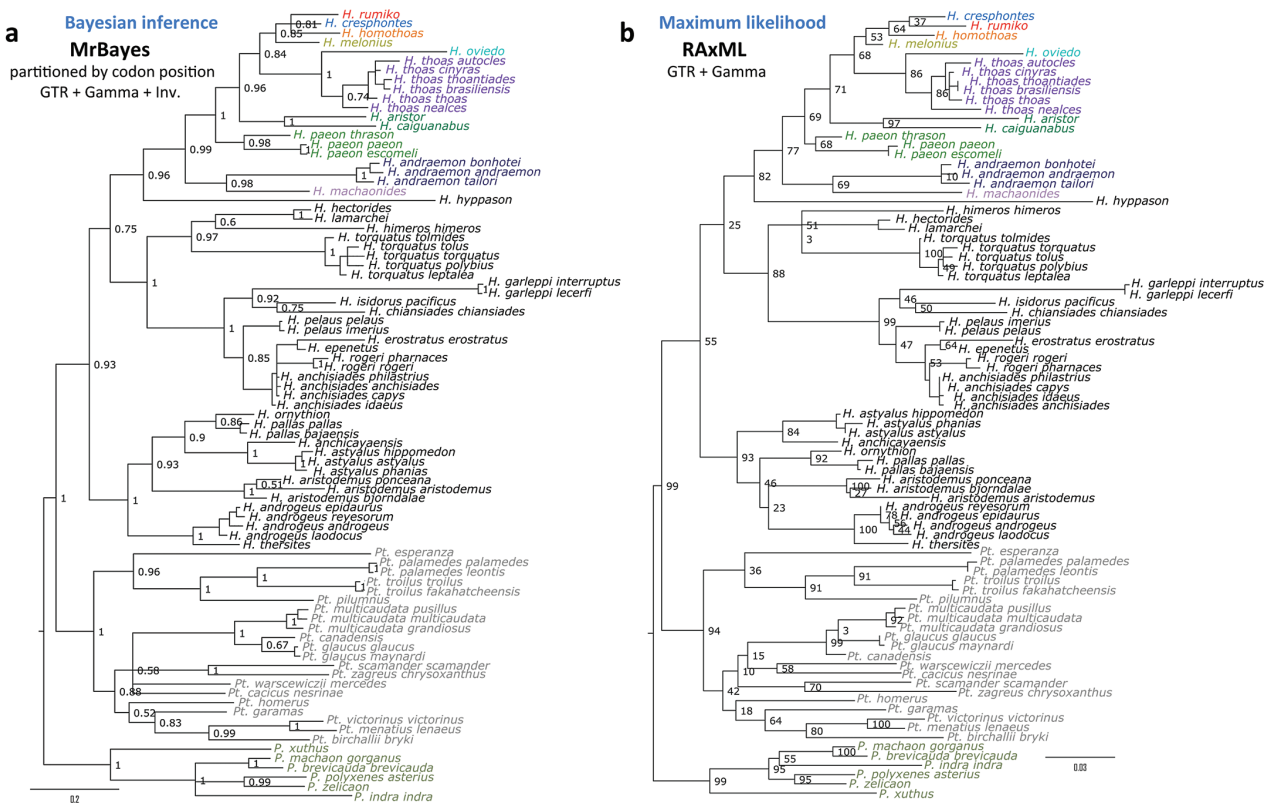

Figure 16. COI DNA barcode trees. Trees of representative sequences of Papilionini reconstructed with different methods: a Bayesian inference using MrBayes (alignment partitioned by codon position, nst=6, rates=invgamma, ratepr=variable), posterior probabilities are indicated by the nodes $\mathbf{b}$ Maximum likelihood method RAxML (-m GTRGAMMA), bootstrap values are indicated. Posterior probabilities are shown by the nodes (omitted within species). Names of different species are shown in different colors. Sequences obtained in this work are those with "NVG-" number (see Supplementary Table 1 for complete data), others are from GenBank (http://genbank.gov/) and are labeled by accessions (letters and numbers, no dashes). Specimens with sequences from GenBank were not examined (except where a photograph was available from the BOLD database) and their identification follows original work, locality, and DNA barcode.

2184 | NVG140320-25 [TAMU]. Mexico: Morelos: 1 ○ Rancho Viejo, 20-Jul-2008, | KS034 [SDMC]. Mexico: Veracruz: 1 đ Fortín de las Flores, Motel Posada Loma, 900 m, 30-Mar-1977, leg. R. O. Kendall \& C. A. Kendall, NVG-2186|NVG14032027 [TAMU]; 1 ð Fortin 13-Aug-1970, leg. B. Douglas, | KS038 [SDMC]. Mexico: Oaxaca: 1 o Tlalixtac, 5 mi N of Oaxaca, 6000', 13-IV-1988, leg. J. Kemner, NVG2281 | NVG140403-09 [TMMC]; 1 ô Candelaria, Candelaria Loxicha, 1500', 29IV-1988, leg. J. Kemner, NVG-2282 | NVG140403-10 [TMMC]; 1 đ km 190 near Zanatepec, 500 ft, 24-Jul-1987, \#14813, NVG-14102H01 [FMNH]; 1 đ Yangul, 1-Apr-1979, leg. J. Stoddard, | KS012 [SDMC]. Mexico: Yucatan: 1 ô Merida, Mar1976, | KS021 [SDMC]. Mexico: Quintana Roo: 1 đ X-Can, 21-May-1963, | KS022 [SDMC]. Honduras: 1 + Escuela Agrícola Panamericana, $30 \mathrm{~km}$ SE Tegucigalpa, 1-May-1985, leg. Vascones, NVG-2221 | NVG140320-62 [TAMU]; 1 o 1 q in copula, $18 \mathrm{~km}$ west of La Ceiba, 27-Jul-1980, leg. R. D. Lehman, NVG-14061A06, -14061A07 [USNM]. El Salvador: 1 ○ San Salvador, 26-Sep-1971, leg. M. Serrano, 
NVG-14081G10 [CSUC]. Costa Rica: $1 \lesssim$ Alajuela, Alajuela Adventist University of Centrali Americana, 15-20-May-1995, leg. J. C. Abbott \& D. Petr, \#308, NVG-2278 | NVG140403-06. Panama: 1 § C. Z., La Pita, 19-Aug-1966, leg. G. B. Small, NVG14061A05 [USNM].

Specimens excluded from the type series. 35 specimens from Texas (mostly central) possessed DNA barcodes of $H$. rumiko, but many displayed morphological characters somewhat intermediate between those of $H$. rumiko and $H$. cresphontes. These specimens with full data are listed in Suppl. material 1 (as H. rumiko, but not paratypes) and are excluded from the type series.

Type locality. USA: Texas: Duval Co., Benavides, CR306, 1.8 mi west of SH339, latitude $27^{\circ} 36^{\prime} 27^{\prime \prime}$, longitude -98 26'29.4", elevation $124 \mathrm{~m}$. This locality is at the sharp bend of the County Road 306, where several shrubs of Colima (Zanthoxylum fagara [L.] Sarg.) are growing by a fence. The egg that developed into the holotype was found on one of these shrubs.

Etymology. The species is named to honor the wife of the first author. Pronounced as 'roo(as in rue)-mee(as in meek)-koh(as in cod). The stress is on the first syllable. The name is a noun in apposition.

Distribution. H. rumiko is recorded from the southwestern United States (mostly southern regions of four states: CA, AZ, NM, and TX) to Panama (DNA barcode data obtained for specimens from Mexico, El Salvador, Honduras, Costa Rica, and Panama). The northernmost barcoded specimen is from northeastern Colorado. In Mexico, $H$. rumiko tends to be absent from deserts and high mountains, but is found elsewhere (Molina and León 2006). In central Texas, H. rumiko is sympatric with its sister species $H$. cresphontes. In Costa Rica and Panama, it is sympatric with $H$. homothoas Rothschild \& Jordan, 1906 (Tyler et al 1994), a likely sister to the ancestor of $H$. cresphontes and $H$. rumiko.

In the 1960s, H. rumiko began expanding its distribution in California northward, and by the 1980s, it has reached central California (Emmel and Emmel 1973, Erickson and Iliff 2004). Citrus was cultivated in California from as early as 1840 s (Laszlo 2007), and the factors that prevented H. rumiko from northward expansion for 120 years are unknown. The increase in ornamental citrus trees may have supported the buildup of $P$. rumiko numbers in southern California and the butterfly can now be commonly found in urban areas. Rue, another host, is very commonly cultivated in southern California today.

Diagnosis. H. rumiko belongs to the genus Heraclides Hübner, [1819] (type species $H$. thoas), because it possesses simple, smooth, U-shaped juxta, which is a synapomorphy for the genus. H. rumiko is in the subgenus Heraclides Hübner, [1819] (type species $H$. thoas), because its uncus is shaped as two paired (i.e., uncus dorsad, brachium ventrad) horn-like processes, similarly to $H$. thoas, and the harpe lacks a spine directed distad and separated at the end on its ventral surface. H. rumiko is from the cresphontes group because the harpe is rounded, without sharp spines. These taxonomic attributions are also supported by the DNA barcode distances and trees (Fig. 15, 16). H. rumiko differs from $H$. melonius in lacking a knob-like blunt projection 

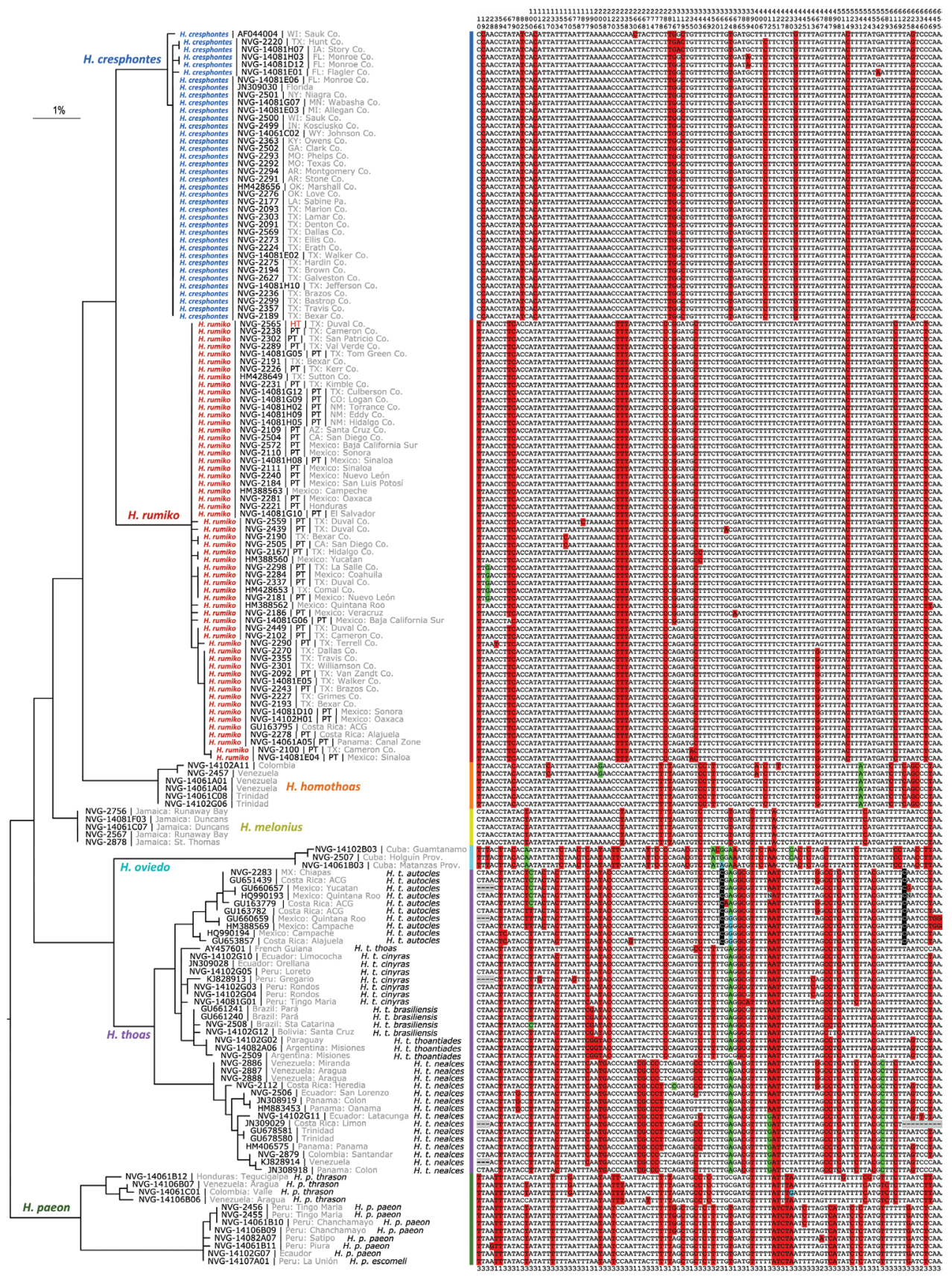

at the distal end of harpe and having restricted or absent orange scaling at the base of ventral hindwing cell $\mathrm{M}_{1}-\mathrm{M}_{2}$. H. rumiko differs from $H$. homothoas in having a simple beak-like, not bifid, pseuduncus. Compared to its sister species $H$. cresphontes, H. rumiko is characterized by (Figs 11, 13): (1) longer and more slender uncus arms, often 
Figure 17. COI DNA-barcodes. Relationships between Heraclides specimens from the cresphontes, thoas and paeon groups in a form of RAxML (Stamatakis 2006) maximum likelihood tree (-m GTRGAMMA). Tree topology is the same as that of the distance tree (Fig. 15). The scale bar corresponding to about $1 \%$ difference in sequences is placed above the tree. Species names are shown by tree clades and are colored. Subspecies names are in black after localities. Sequences obtained in this work are labeled by "NVG-" number, those from GenBank (http://genbank.gov/) are labeled by accessions (letters and numbers, no dashes). Only selected sequences are shown (different haplotypes or different localities), data for additional NVG- specimens are in Supplementary Table 1. Barcode sequences with invariant positions removed are shown on the right. Positions are numbered according to the barcode sequence of $H$. rumiko holotype (see text) and the numbers are shown above the sequences (e.g., the first position shown is 10 and the last is 655). Most common nucleotide in each position is not highlighted, less common are highlighted in color, giving each group of sequences "barcode"-like appearance different for each species. Location of each position in a codon (first, second, or third base) is shown below the alignment. Specimens with sequences obtained from GenBank were not examined (except where a photograph was available) and their identification follows DNA barcode.

strongly curving inwards; (2) brachium arms that project from the base of uncus on the inner (and not outer) side, and are visible below uncus in dorsal view, not hidden beneath uncus; (3) in lateral view, an uncus and brachium that point away from each other: posterodorsad (uncus) and posteroventrad (brachium), and not in the same direction; (4) bases of uncus and brachium that are weakly fused, with weaker sclerotization at the base of brachium; (5) two continuous yellow stripes dorsally from head to thorax, instead of separate spots; (6) more slender wings with longer tails; (7) smaller marginal yellow spots on the forewing; (8) a background-colored spot on yellow central band in cell $R_{5}-M_{1}$ that is larger, with better defined edges; (9) a submarginal forewing band mostly of 3 spots, not 4; (10) a black median band on ventral hindwing that is more expressed and straight; (11) a COI DNA barcode sequence that differs by about $3 \%$. Seventeen positions are consistently invariant in either $H$. rumiko or $H$. cresphontes, but different between them on a sample of $183 \mathrm{H}$. rumiko and 112 $H$. cresphontes specimens across the range (Figs 17, 18, Suppl. material 1). These 17 positions are listed here in the format " $\mathrm{kX}$ (not $\mathrm{Y}$ )", where $\mathrm{k}$ is a sequential number of the position (numbering is from 1 to 658 for the barcode sequence of $H$. rumiko holotype shown above), $\mathrm{X}$ is a nucleotide in $H$. rumiko barcodes and $\mathrm{Y}$ is a nucleotide in $H$. cresphontes barcodes: $10 \mathrm{~T}$ (not C), $19 \mathrm{~T}$ (not C), $79 \mathrm{C}(\operatorname{not} \mathrm{T}), 82 \mathrm{C}(\operatorname{not} \mathrm{T})$, $106 \mathrm{~T}$ (not C), $223 \mathrm{~T}$ (not C), $235 \mathrm{~T}$ (not C), $238 \mathrm{~T}$ (not A), $286 \mathrm{C}(\operatorname{not} \mathrm{T}), 287 \mathrm{C}$ (not T), 319 A (not C), 340 C (not T), $364 \mathrm{C}(\operatorname{not} T), 433$ A (not G), $616 \mathrm{C}$ (not $\mathrm{T}$ ), $628 \mathrm{~A}$ (not $\mathrm{G}$ ), $640 \mathrm{~T}$ (not $\mathrm{C}$ ). While these positions distinguish the two species in a sample of 295 specimens, some of the positions may show variation when a larger sample of sequence is accumulated.

Female genitalia are very variable in both species (Fig. 12), and we were not able to find differences between the two species. Also, due to significant variation in many characters, not all specimens might be readily identifiable, especially in central Texas, where $H$. rumiko and $H$. cresphontes likely hybridize at least to some extent as judged from intermediate characters in some specimens (Fig. 11E). Male genitalia, stripes on 


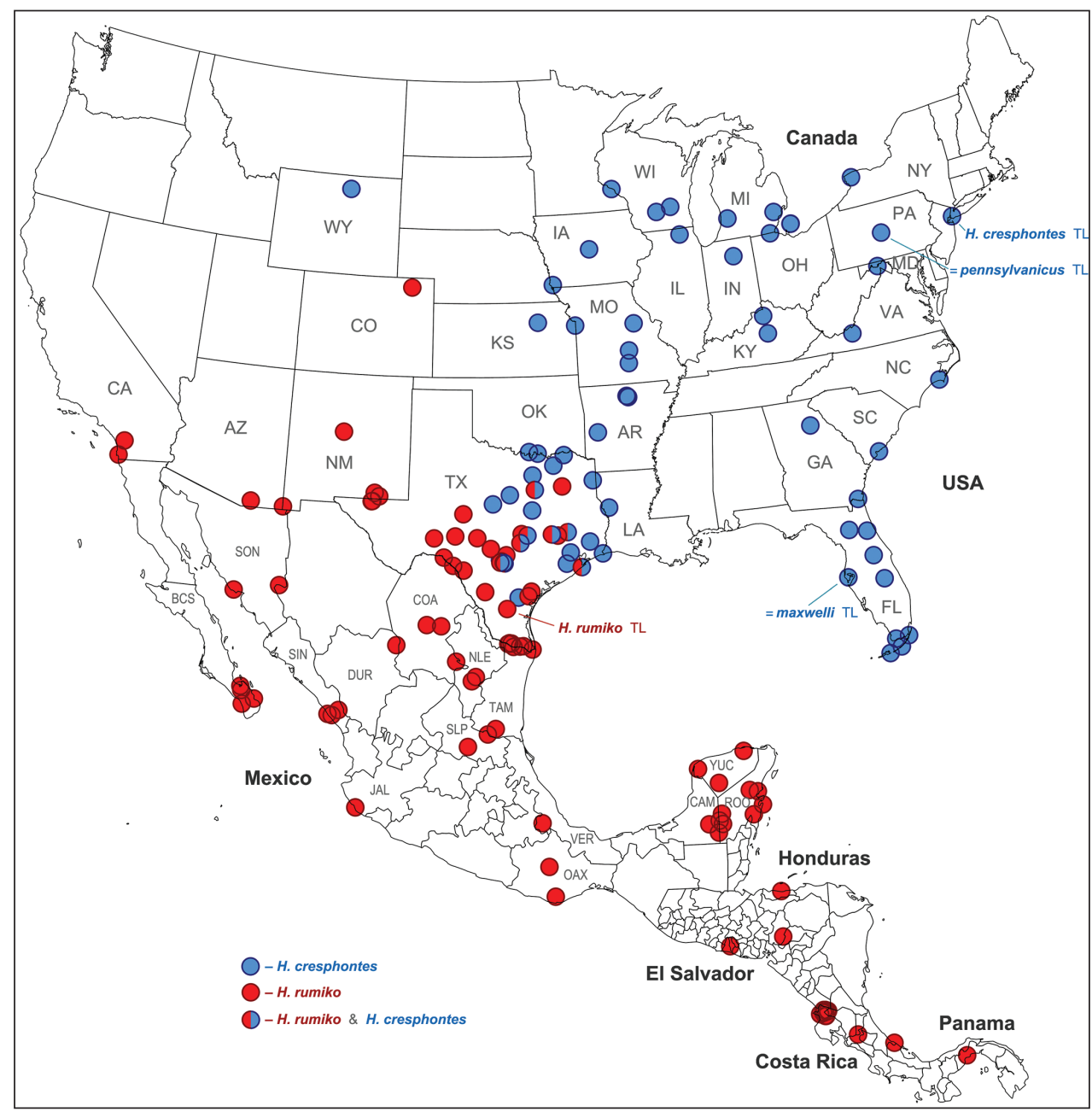

Figure 18. Localities of $H$. cresphontes and $H$. rumiko specimens with available DNA barcode information. Color of circles corresponds to species: H. cresphontes - blue (based on 112 DNA COI barcode sequences, 103 obtained in this work); H. rumiko - red (based on 183 barcodes, 146 obtained in this work), split red/blue circles mark localities where both $H$. cresphontes and $H$. rumiko were recorded. Type localities for taxa with available names are indicated with a corresponding name followed by "TL". We treat Papilio cresphontes var. maxwelli Franck, 1919 \& Papilio cresphontes pennsylvanicus F. Chermock \& R. Chermock, 1945 as junior subjective synonyms of $H$. cresphontes. Countries and states (for USA and Mexico) with records are labeled.

the neck and DNA barcodes are the most reliable characters for identification. Genitalia morphometrics involving 3 measures completely separates the two species (excluding specimens from central Texas) with a hiatus between them when a weighted sum of the 3 measures is used (Fig. 11E, along horizontal axis). None of the three measures is sufficient when used separately due to variation. The best of the three, the angle be- 


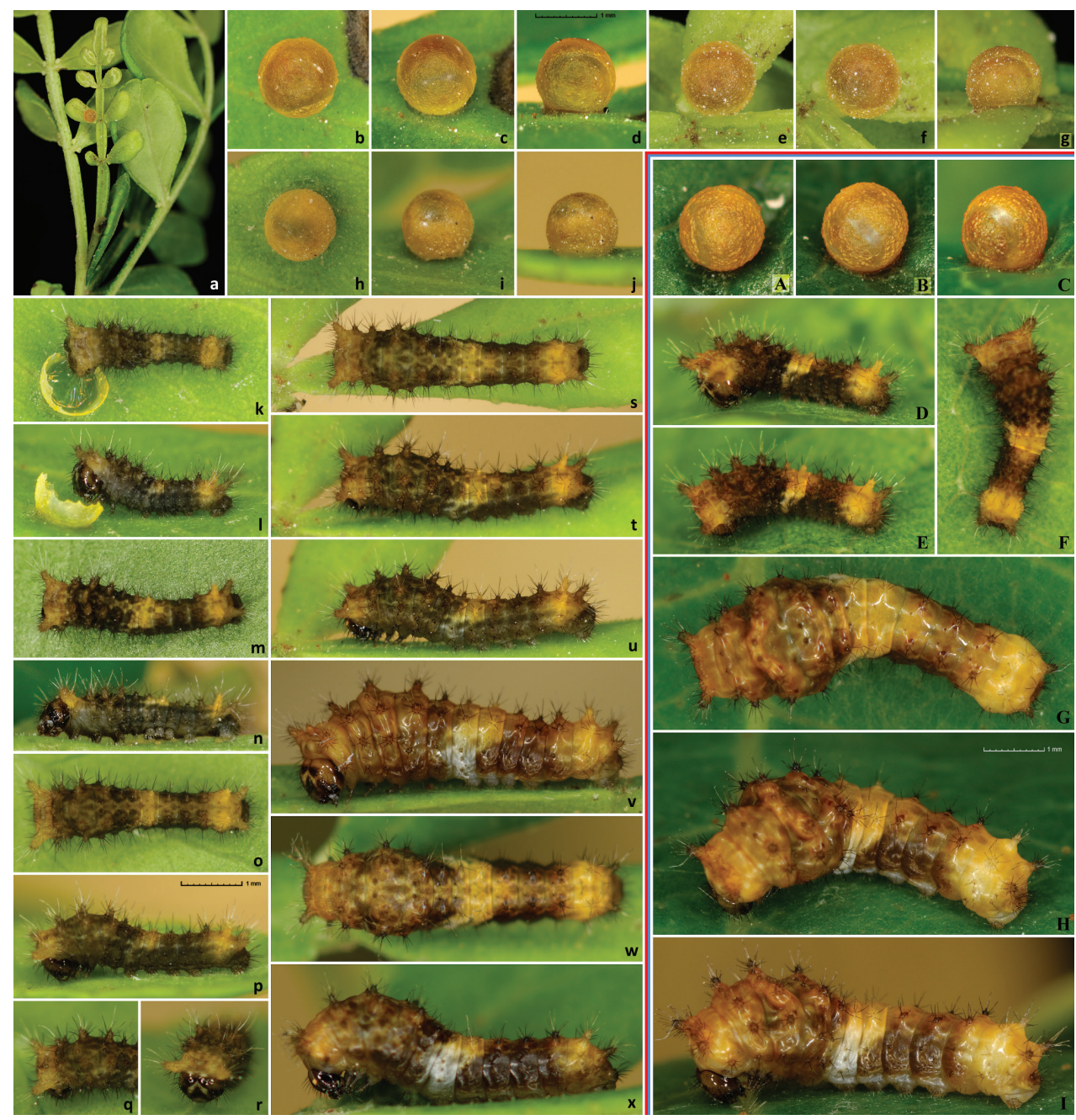

Figure 19. Life history: eggs and $1^{\text {st }}$ instar caterpillars. a-x H. rumiko types, USA: TX: Duval Co., Benavides A-I H. cresphontes, USA: TX: Denton Co., Grapevine Lake, Murrell Park a-j, A-C ova; k-x, D$\mathbf{I} 1^{\text {st }}$ instar caterpillars; $1 \mathrm{~mm}$ scale shown on panels $\mathbf{d}, \mathbf{p}$ and $\mathbf{H}$ refers to all images except $\mathbf{a}$, which shows a typical position for an egg on a fresh leaf. In Figs 19-23, dorsal, dorsolateral, and lateral views are shown for most individuals, supplemented with anterior and posterior views for some caterpillars. Sexes and voucher

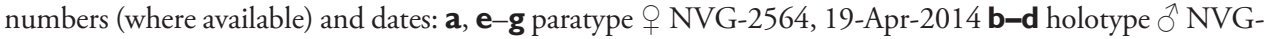
2565, 19-Apr-2014; h-I paratype + NVG-2563, 19-Apr-2014 (h-j), + NVG-2563, 20-Apr-2014 (k-l) m-n paratype $\lesssim$ NVG-2559, 19-Apr-2014 o-r paratype + NVG-2564, 22-Apr-2014 s-u paratype $\widehat{\sigma}$ NVG-2559, 20-Apr-2014 $\mathbf{~}$ holotype $\lesssim$ NVG-2565, 25-Apr-2014 $\mathbf{w}-\mathbf{x}$ paratype $\lesssim$ NVG-2559, 22-Apr2014 A-I $\delta$ NVG-2760,16-Jun-2014 (A-C), 19-Jun-2014 (D-F), 21-Jun-2014 (G-I).

tween uncus and brachium in lateral view, identifies all specimens but one. The failed specimen possesses brachium strongly curved dorsad, but other two measures in its genitalia correctly identify this specimen. Linear combination of the measures is more 


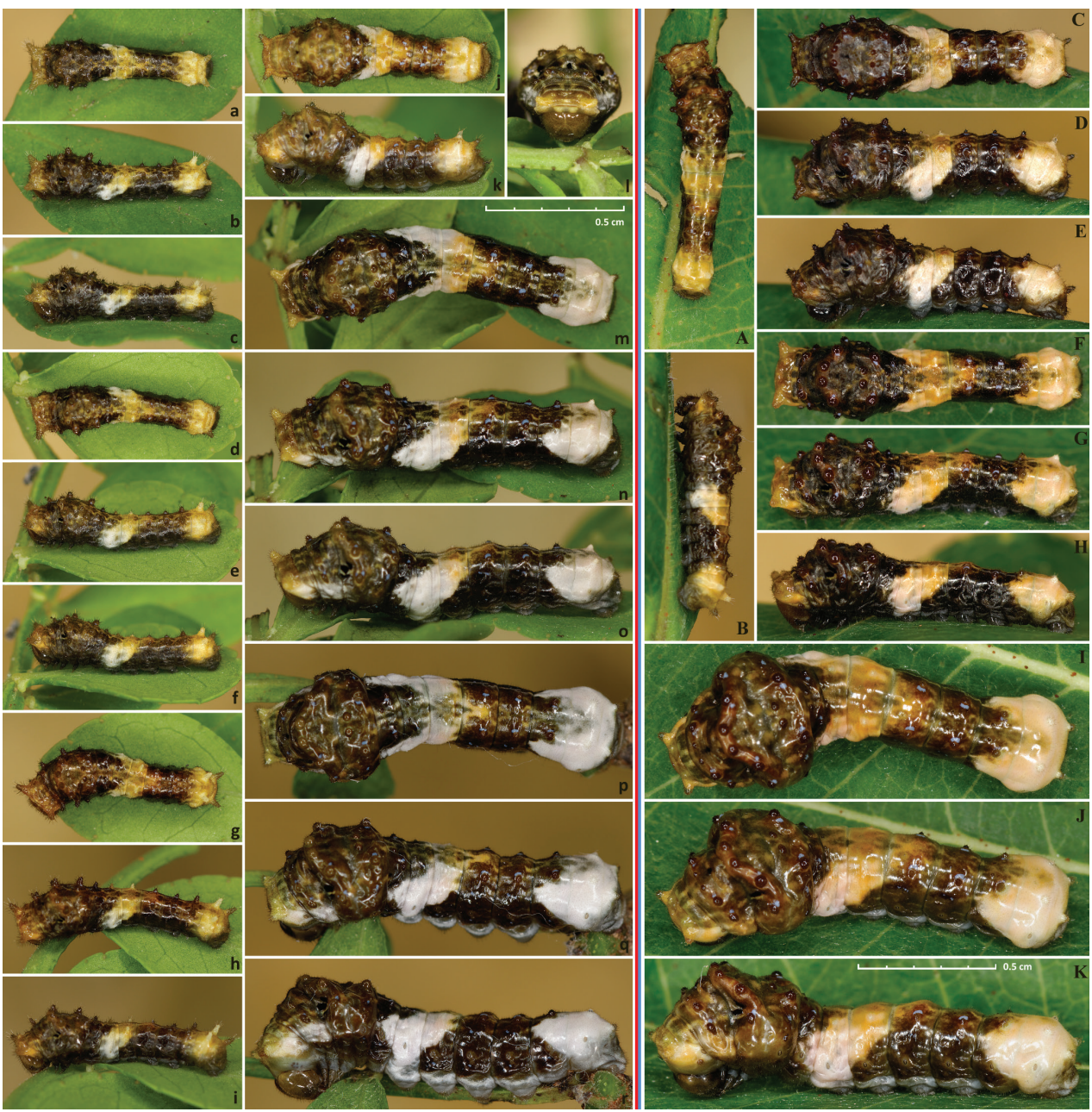

Figure 20. Life history: $2^{\text {nd }}$ and $3^{\text {rd }}$ instar caterpillars. a-r $H$. rumiko, USA: TX: Duval Co., Benavides A-K H. cresphontes, USA: TX: Denton Co., Grapevine Lake, Murrell Park a-k, A-E $2^{\text {nd }}$ and $\mathbf{k}-\mathbf{r}, \mathbf{F}-\mathbf{K} 3^{\text {rd }}$ instar caterpillars; $0.5 \mathrm{~cm}$ scale shown on panels $\mathbf{m}$ and $\mathbf{K}$ refers to all images. Sexes and voucher numbers (where available) and dates: a-c paratype $q$ NVG-2564, 25-Apr-2014 d-f paratype + NVG-2563, 25-Apr-2014 g-i larva \#7 (died), 29-Apr-2014 j-k paratype $\widehat{~}$ NVG-2559, 25-Apr-2014 Io paratype $\delta$ NVG-2559, 27-Apr-2014 p-r paratype + NVG-2564, 29-Apr-2014 A-B, F-K $\delta$ NVG2760, 22-Jun-2014 (A-B), 24-Jun-2014 (F-H), 26-Jun-2014 (I-K) C-E $\odot$ NVG-2741, 16-Jun-2014.

robust to variation than a single measure and should be used for more confident identification. Similar results were obtained with a combination of 4 facies measures, one of which was the continuity of the stripe on the neck (Fig. 11E, along vertical axis).

Life history, foodplants, and phenology (Figs 19-24). The following observations were made in Texas and southern California. Eggs are laid singly on young leaves (Fig. 




Figure $2 \mathbf{I}$. Life history: $4^{\text {th }}$ and $5^{\text {th }}$ instar caterpillars. a-n H. rumiko, USA: TX: Duval Co., Benavides A-K $H$. cresphontes, USA: TX: Denton Co., Grapevine Lake, Murrell Park a-e, A-F $4^{\text {th }}$ and $\mathbf{f}-\mathbf{n}$, G-K $5^{\text {th }}$ instar caterpillars; $1 \mathrm{~cm}$ scale shown on panels $\mathbf{C}$ and $\mathbf{I}$ refers to all images. Sexes and voucher numbers (where available) and dates: $\mathbf{a}-\mathbf{b}, \mathbf{f}-\mathbf{n}$ is the same individual (larva \#2, died, shown in Fig. 22 a-c), 24-Apr-2014 (a-b), 29-Apr-2014 (f-j), 29-Apr-2014 (k-n) c-e larva \#1 (died), 24-Apr-2014 A-C $\curvearrowright$ NVG-2740, 16-Jun-2014 D-F + NVG-2741, 21-Jun-2014 G-K + NVG-2741, 26-Jun-2014.

19a) and shoots of the host plants from Rutaceae family: Zanthoxylum fagara [L.] Sarg, Ptelea trifoliata L., Amyris texana (Buckley) P. Wilson, and Casimiroa greggii (S. Watson) F. Chiang in Texas, or Ruta graveolens L. and Citrus spp. in both states, and likely others. For instance, ovipositions were recorded on Geijera parviflora Lindl. in Tucson, Pima Co., Arizona and females were observed around these trees in Los Angeles County, CA (Brian Banker, personal observations). Eggs are round, 1.1-1.6 $\mathrm{mm}$ in diameter, coated with a substance giving the surface a granular appearance (Fig. 19b-j). Color of egg is pale yellow when laid, gradually changing to dull orange-brown. H. rumiko eggs are typically smaller 


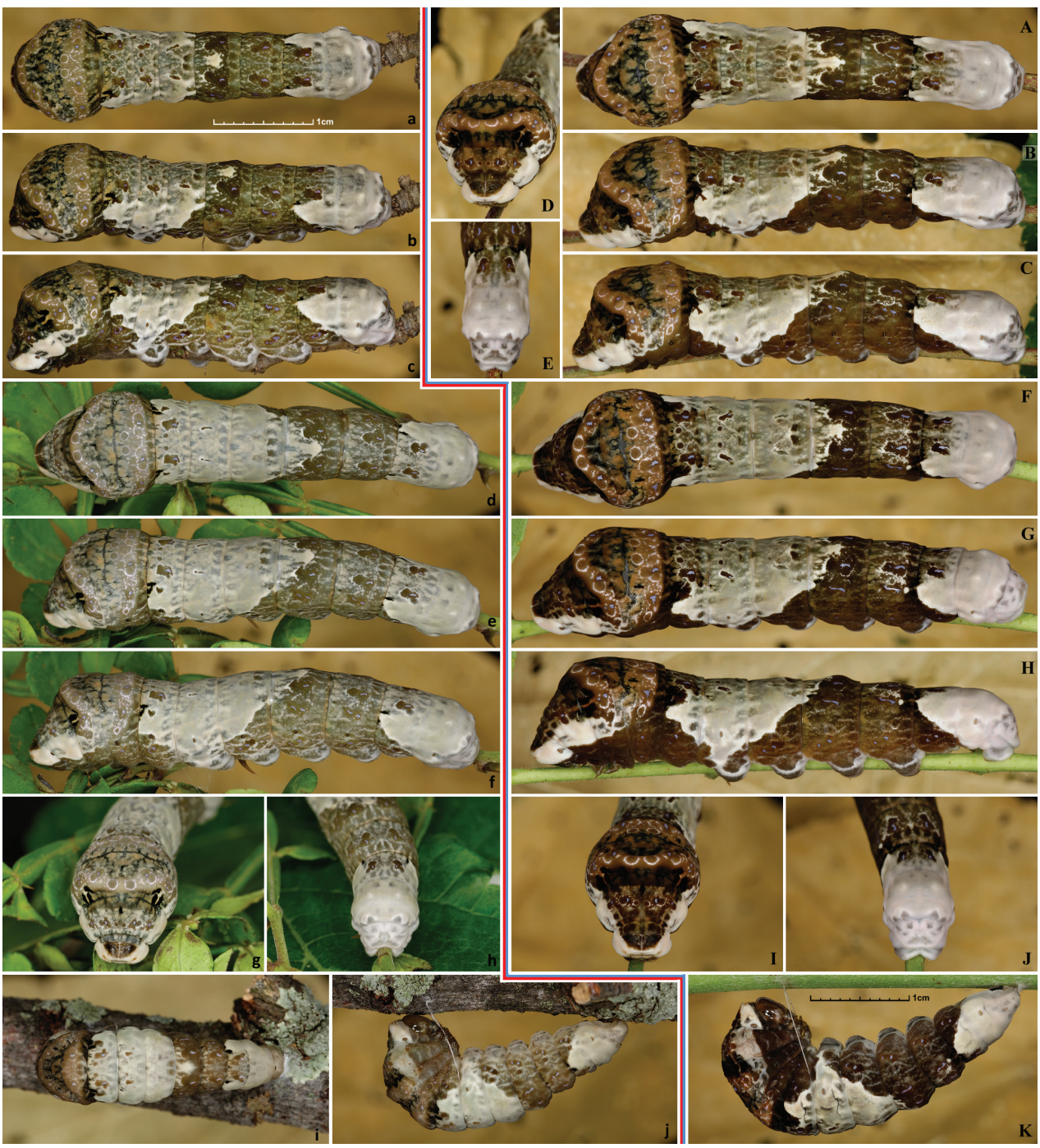

Figure 22. Life history: $5^{\text {th }}$ instar caterpillars and prepupae. a-j $H$. rumiko, USA: TX: Duval Co., Benavides A-K H. cresphontes, USA: TX: Denton Co., Grapevine Lake, Murrell Park a-h, A-J $5^{\text {th }}$ instar caterpillars and $\mathbf{i}-\mathbf{j}, \mathbf{K}$ prepupae; $1 \mathrm{~cm}$ scale shown on panels $\mathbf{a}$ and $\mathbf{K}$ refers to all images. Sexes and voucher numbers (where available) and dates: a-c larva \#2, died (shown in Fig. 21a-b, f-n), 1-May-2013 d-h paratype $\$$ NVG-2564, 11-May-2014 (adult Figs 9, 10) i-j paratype ô NVG-2559, 11-May-2014 A-E 26-Jun-2014 F-K $\lesssim$ NVG-2740, 21-Jun-2014 (F-J) \& 23-Jun-2014 (K).

than $H$. cresphontes eggs and are finer grained on the surface (Fig. 19A-C). Eggs hatch in 7-10 days. Prior to hatching, larval head can be seen through the eggshell.

Larva eats egg shell upon hatching (Fig. 19k, l). $1^{\text {st }}$ instar is $3-5 \mathrm{~mm}$ in length (Fig. $19 \mathrm{k}-\mathrm{x}$ ), covered with prominent setae, head capsule yellow-brown with dark-brown spots and paler caret in the middle, body pattern resembles bird-droppings similarly 

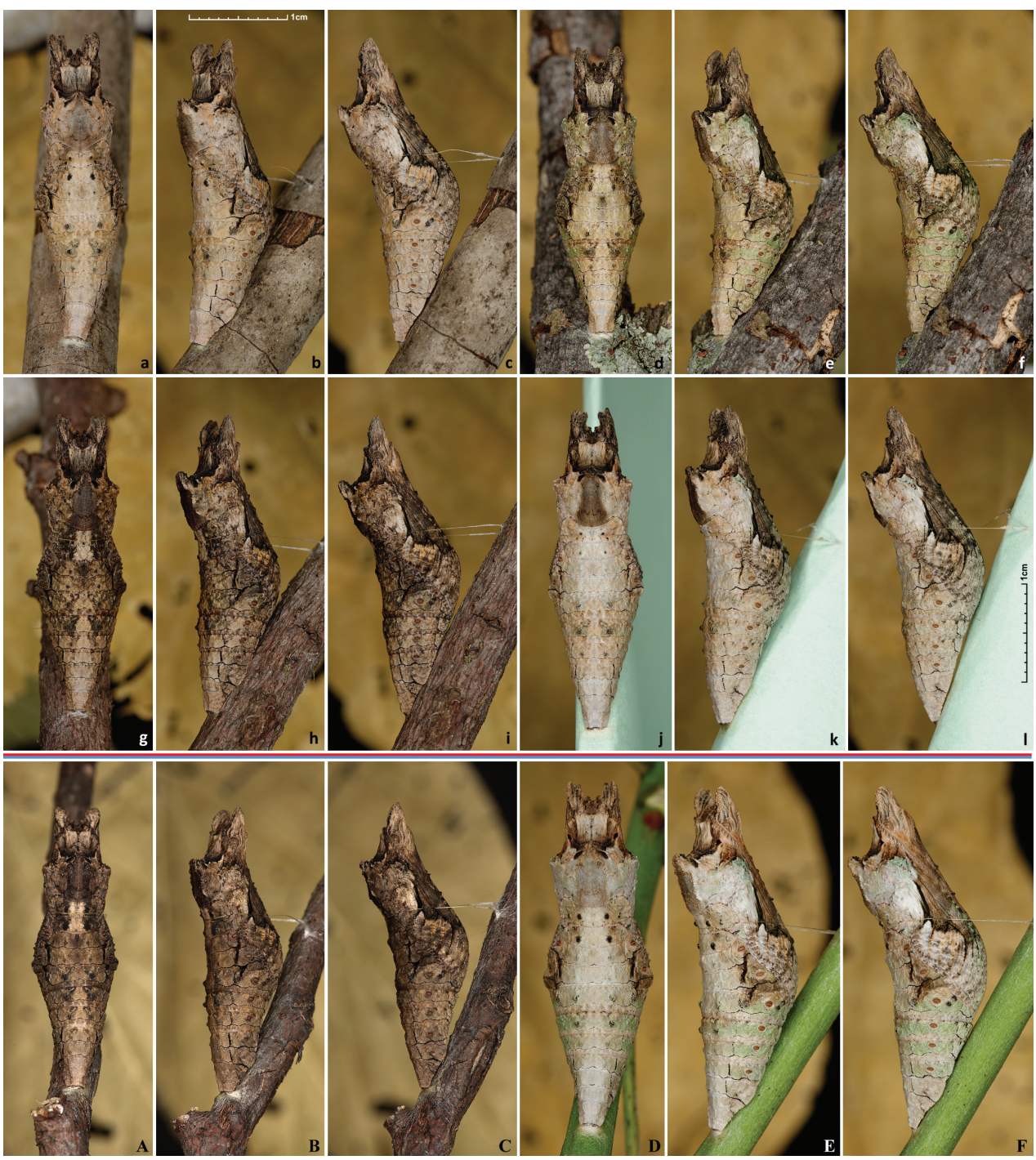

Figure 23. Life history: pupae. a-I H. rumiko types, USA: TX: Duval Co., Benavides A-F $H$. cresphontes, USA: TX: Denton Co., Grapevine Lake, Murrell Park; $1 \mathrm{~cm}$ scale shown on panels $\mathbf{b}$ and $\mathbf{I}$ refers to all images. Sexes and voucher numbers (where available) and dates: a-c holotype ô NVG-2565, 17-May2014 d-f paratype $\widehat{\jmath}$ NVG-2559, 17-May-2014 g-i paratype $q$ NVG-2563, 17-May-2014 j-I paratype + NVG-2564, 17-May-2014 (adult Figs 9, 10) A-F 28-Sep-2014 D-F § NVG-2740, 26-Jun-2014.

to many other Papilionidae. Larva bears this pattern through the end of development, but it charges somewhat between instars. $2^{\text {nd }}$ instar is $5-11 \mathrm{~mm}$ (Fig. 20a-l), head from this instar on is uniformly brownish without darker spots. $3^{\text {rd }}$ instar is $11-16 \mathrm{~mm}$ (Fig. $20 \mathrm{k}-\mathrm{r}$ ), $4^{\text {th }}$ instar is $16-30.0 \mathrm{~mm}$ (Fig. 21a-e), and $5^{\text {th }}$ instar is $30-50 \mathrm{~mm}$ (Figs $21 \mathrm{f}-\mathrm{n}$, $22 \mathrm{a}-\mathrm{h})$. While the first 4 instars appear shiny, the $5^{\text {th }}$ one is matte. Larval growth is 

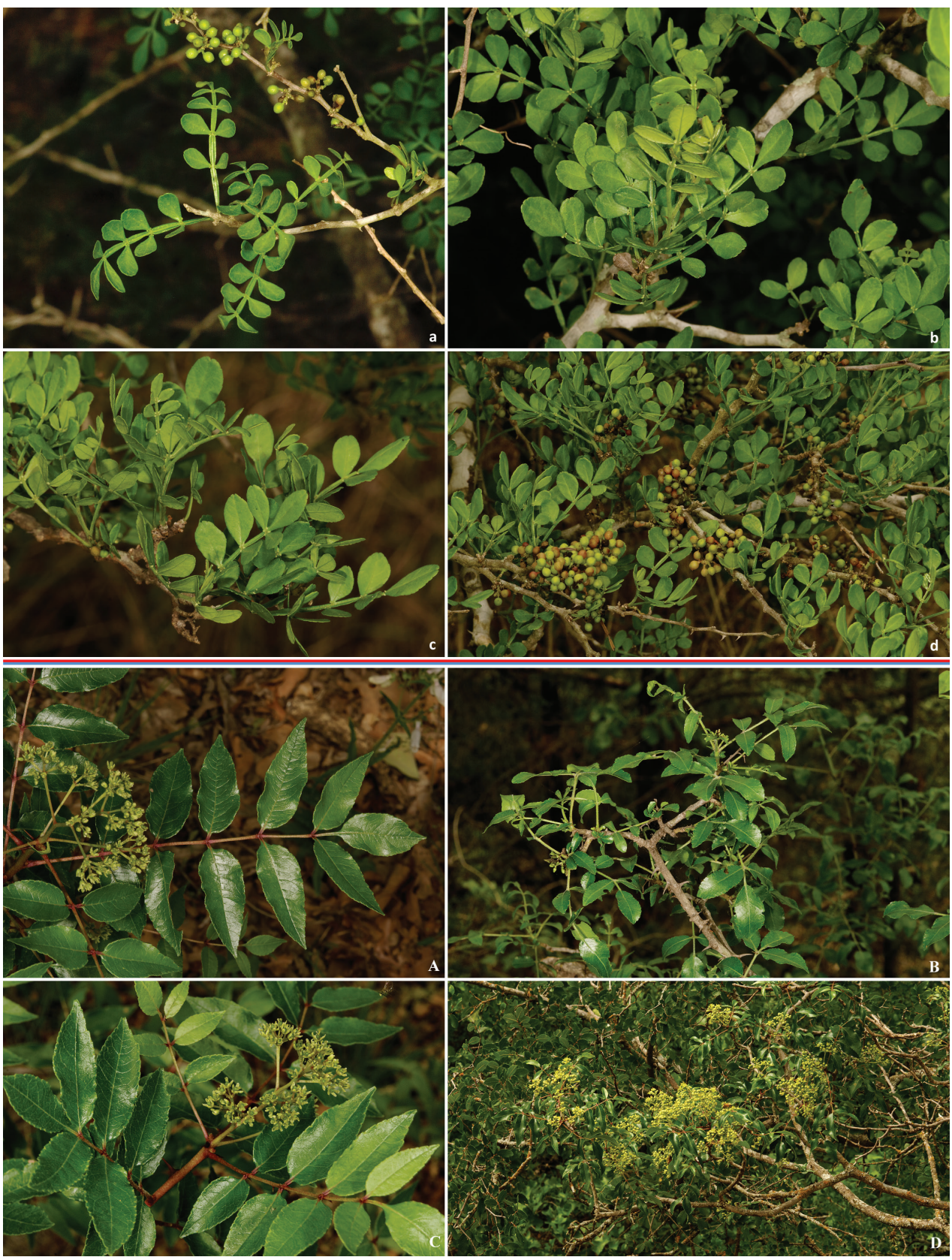

Figure 24. Foodplants most commonly used by Heraclides caterpillars. a-c Zanthoxylum fagara [L.] Sarg (Colima, Lime Prickly-ash), USA: TX: Duval Co., Benavides, 19-Apr-2014, used by H. rumiko A-C Zanthoxylum clava-herculis L. (Hercules's club, Pepperwood), USA: TX: Denton Co., Grapevine Lake, Murrell Park, 26-Apr-2014, used by H. cresphontes. 
rapid under indoor rearing condition with ambient room temperature, taking only about 9 days to reach ultimate instar. When a late instar larva is startled, it lifts its head and inflates the thorax, revealing the eyespots on meta-thorax (Fig. 22g). If disturbed further, it everts red osmeterium from behind the head. Early instar larva tends to use osmeterium right away when disturbed, and osmeterium of the first instar is yellowish. Right before pupation, the color of larva changes little, still resembling bird droppings (Fig. 22i, j), but becoming slightly more uniform and paler. Much more drastic prepupal color changes are observed in some other Papilionidae, such as Pterourus rutulus (Lucas, 1852) and Pt. eurymendon (Lucas, 1852), whose larvae turn from green to brown (Shiraiwa 2009). Since the larva is searching for suitable pupation sites on brown tree branches rather than green leaves, such color change is adaptive. Ultimate instar Heraclides larvae are already brown and rest on branches and not leaves to begin with. H. cresphontes caterpillars (Figs 19D-I, 20A-K, 21A-K, 22A-K) are very similar to $H$. rumiko, but most caterpillars are browner, more vividly colored and are less gray and less green, especially in the ultimate instar.

Pupa, 26-36mm in length (Fig. 23a-l), is mottled pale to grayish and dark brown, resembling surface of a tree or branch it is attached to. Some pupae develop greenisholive spots (Fig. $23 \mathrm{~d}-\mathrm{f}$ ). The darkness of a pupa is frequently determined by the color of the surface it rests on. E.g., the darkest pupa was formed on a dark branch (Fig. $23 \mathrm{~g}-\mathrm{i}$ ). The palest one (Fig. 23j-l) is attached to a pale-green paper sheet covering the pupation container with the goal to induce a pale pupa. The pupa on a branch with greenish lichens developed the largest amount of green (Fig. 23d-e). H. cresphontes pupae are very similar, but are typically larger (Fig. 23D-F), although poor foodplant condition could result in smaller pupae (Fig. 23A-C). Adult either emerges from pupa in 1 to 2 weeks, or pupa goes into diapause for several months. Pupae overwinter. Pupae can be brought out of diapause prematurely with increase of temperature (Brian Banker, unpublished). Due to dark coloration of pupal wing cases, it is difficult to see when the adult is ready to eclose. The best indicator of pupae being near eclosion might be the dark stripe showing through the median on the dorsal side of an abdomen, which are usually paler and most transparent in pupae.

In south Texas (e.g., near the type locality in Duval County), H. rumiko larvae are found on small to medium size Colima shrubs, Zanthoxylum fagara [L.] Sarg (Fig. $24 a-d)$ throughout ranches and particularly along the roads, which males use as flying corridors. Early instar larvae rest on leaves, ultimate instar caterpillars rest on branches, which they resemble in color. Adults can be found on wing during most of the year except the coldest months. Adults are more common from April to September, when emergences peak every 1.5 months with exact timing dictated by the severity of winter and the amount of rain. In southern California adults fly from late February through mid-November. In San Diego, California, the larvae are often found on citrus trees in gardens and orchards. The adults frequent the cities where many ornamental citrus plants grow, and the number of adults seen increases during August and September. H. cresphontes in Texas uses Pepperwood Zanthoxylum clava-herculis L. (Fig. 24A-D) as the major caterpillar host. 


\section{Taxonomic adjustments in Heraclides}

Subgenera of Heraclides. To gain better understanding of Heraclides taxonomy, we determined new and retrieved available COI DNA barcodes for a number of species and subspecies from the Tribe Papilionini. The resulting distance dendrogram and trees are shown in Figs 15, 16. Although our results are not expected to fully reflect phylogeny accurately due to short length of DNA barcodes (654 base pairs) and possible discordance between mitochondrial and nuclear genomes, it agrees very well with the results obtained on a much larger sample of positions (Zakharov et al. 2004)—i.e., the three genera of Neotropical Papilionini: Papilio Linnaeus, 1758, Pterourus Scopoli, 1777, and Heraclides Hübner, [1819] are monophyletic and well-separated in all analyses and will all substitution models. Topology within each genus also mostly agrees with that obtained previously (Zakharov et al. 2004), although position of certain branches like Pt. esperanza (Beutelspacher, 1975) and Pt. homerus (Fabricius, 1793) might have been influenced by long branch attraction in some trees (Figs 15, 16). The differences in topology between the trees obtained by different methods are mostly confined to less confident nodes as judged by Bootstrap, Posterior probability and Bremer support values, and typically involve the order of basal branching in each genus or near the leaves of the tree (between subspecies). It should be noted that to simplify illustrations, each taxon is represented by a single sequence on Figs 15 and 16a-b. However, for most taxa we obtained (Suppl. material 1) and analyzed several sequences frequently from different localities.

Species in the genus Heraclides group into five prominent clades that can be treated as subgenera (Fig. 15). Four of these subgenera have been named: the nominate (type species: H. thoas); Calaides Hübner, [1819] (type species: Heraclides androgeus (Cramer, 1775)); Troilides Hübner, [1825] (type species: Troilides tros Hübner, [1825], considered a subjective synonym of $H$. torquatus polybius (Swainson, 1823)); Priamides Hübner, [1819] (type species: Priamides hipponous Hübner, [1819], considered a subjective synonym of $H$. anchisiades anchisiades (Esper, 1788)). The fifth subgenus is unnamed and consists of a single species, $H$. hyppason (Cramer, 1775), which is characterized by unique phenotype, thus it is not surprising that it stands out from the rest. Statistical support for the relationships between the five subgenera is low, and their branching order is inconsistent between different methods, except that Troilides is a likely sister of Priamides. Therefore we show the rest as a quadfurcation in the dendrogram (Fig. 15), assuming the order between them unresolved. Interestingly, in many analyses, $H$. hyppason was placed as a sister to Heraclides (Fig. 16a) despite significant differences in facies. This placement of $H$. hyppason was also suggested by Lewis et al. (2014). Regardless of its exact placement, both studies suggest significant divergence of $H$. hyppason from other taxa. also apparent from its facies.

Subgenus Heraclides. Species with available barcode sequences in the subgenus Heraclides can be partitioned into five species groups. The cresphontes group includes 
four species: $H$. cresphontes, $H$. rumiko, $H$. homothoas, and $H$. melonius. Relationships between them are statistically unresolved, but the tree topology is reasonable. H. melonius splits out first, in agreement with its isolation in Jamaica and more significant differences in genitalia of both sexes: e.g., long pseuduncus (H. melonius was originally described as a subspecies of $H$. thoas), harpe with a terminal knob, vestigial labella postvaginalis, and much enlarged vestibular plates. $H$. rumiko is a sister to $H$. cresphontes in accord with pronounced similarities between these two species.

Analysis of the thoas group revealed that the Cuban taxon is very distant from the rest, showing more than $5 \%$ difference in COI barcodes, a difference much larger than the divergence within the cresphontes group falling within 3.5\% (Figs 15, 16). This barcode difference correlates well with pronounced genitalic differences, both in males and females: valva is more elongated and with a longer harpe extending into a terminal spine almost reaching the distal end of valva; lamella postvaginalis is smaller and vestibular plates are more robust with larger, and almost square, inner lateral processes. Its wings are characterized by deeper yellow ventral side with prominent blue patches on hindwing. These differences imply that Heraclides oviedo (Gundlach, 1866), reinstated status, is a strongly differentiated species and not a subspecies of $H$. thoas.

In agreement with Lewis et al. (2014), endemics of Hispaniola and Cuba H. aristor and $H$. caiguanabus fall within the subgenus Heraclides, and we define the aristor group to encompass these two sister species (Fig. 15). The exact placement of this clade within the subgenus was inconsistent between different methods and parameter sets, but it is possible that they are closer related to cresphontes and thoas groups than the paeon group (Fig. 16). Indeed, morphologically, these Caribbean species are similar to $H$. cresphontes and $H$. thoas (e.g., more robust uncus is more similar to $H$. thoas than to $H$. paeon), but appear visually distinct due to the absence of the central band across wings.

The machaonides group consists of two species: H. machaonides (Esper, 1796) and very distant from it $H$. andraemon Hübner, [1823] with its three subspecies: nominate, H. a. bonhotei (Sharpe, 1900), and H. a. tailori (Rothschild \& Jordan, 1906), which are rather close to each other in DNA barcodes (within 1.5\%). Limited divergence in DNA is consistent with morphological similarities, and these three taxa are best treated as subspecies of $H$. andraemon.

Subgenus Calaides. While we have not performed detailed analysis of other subgenera in Heraclides, we notice and correct two inconsistencies between the current taxonomy and similarities of DNA barcodes in the subgenus Calaides (Figs 15, 16). In agreement with Lewis et al. (2014), we see that Heraclides astyalus (Godart, 1819) is paraphyletic with regard to Heraclides ornythion (Boisduval, 1836) (Figs 15, 16). Thus, $H$. pallas (G. Gray, [1853]), reinstated status, with its subspecies $H$. $p$. bajaensis (J. Brown \& Faulkner, 1992), new combination, are not conspecific with $H$. astyalus (Godart, 1819). Indeed, DNA barcode difference between $H$. pallas and $H$. astyalus is $4.6 \%$, which is significantly larger than the $2.6 \%$ between $H$. pallas and $H$. ornythion. In male genitalia, $H$. pallas differs from $H$. astyalus in having a thicker and shorter spike on the ventral side of harpe (the spike does not extend 
much past the harpe distal end), and the rasp-like ridge of harpe is perpendicular to the smooth edge of harpe (Lewis 2010, Rothschild and Jordan 1906). In H. astyalus, the spike protrudes distad clearly beyond the end of harpe and almost reaches the edge of valva, and the rasp-like ridge of harpe is almost parallel to the smooth edge of harpe (Lewis 2010, Rothschild and Jordan 1906). In female genitalia of $H$. pallas, the inner lateral processes of the vestibular plates are wider, with a larger number of smaller teeth at the edges (Lewis 2010). Furthermore, we see (Figs 15, 16) that H. anchicayaensis Constantino, Le Crom \& Salazar, 2002, new status, described from western Colombia and characterized by narrower bands and dorsal hindwing submarginal lunules differs by $3.5 \%$ in barcode from $H$. astyalus populations, which have very similar barcodes from Colombia to Argentina in all three subspecies. Additionally, $H$. anchicayaensis is apparently sympatric with $H$. astyalus hippomedon (C. Felder \& R. Felder, 1859) in Colombia (Lewis 2010).

Discrepancy between barcodes and morphology. Generally, we see excellent agreement of the DNA barcode trees (Figs 15, 16) with phylogeny obtained on longer sequences (Zakharov et al. 2004) and traditional views about relationships between Papilionini (Tyler et al. 1994). However, the most obvious discrepancy is the placement of H. garleppi (Staudinger, 1892) within Priamides by DNA barcodes, while wing patterns (and traditional view based on similarities to $H$. torquatus (Cramer, 1777)) argue for its affinity with Troilides (Lewis 2010, Tyler et al. 1994). It has been suggested that $H$. garleppi might be a hybrid (Tyler et al. 1994), or a taxon of hybrid origin. Distinctness of genitalia and DNA barcodes argues that it is a good species, but the presence of a barcode very different from $H$. torquatus may indeed suggest hybridizations leading to the origin of this species. This discrepancy between barcodes and morphology needs to be investigated, but Lewis et al. (2014) show the same position of $H$. garleppi in their tree as in ours, and their results use morphological characters in addition to DNA barcodes. Regardless of such discrepancies, the major conclusions of this section, while hinted by DNA barcodes, are substantiated by characters in male and female genitalia and facies, and are consistent with the knowledge about Papilionini from the literature (Tyler et al. 1994).

\section{Synonymic list for the $H$. cresphontes group}

To summarize the nomenclature of the $\mathrm{H}$. cresphontes group, we provide a synonymic list of its species. Name combination from the original description is used for each synonym (= subjective synonyms; = $\dagger$ objective synonyms; = $\neq$ unavailable names) and for species is given after "|". Format of the data: reference to the description | category of a primary type (HT holotype, ST syntypes, LT lectotype, NT neotype) - type locality; collection where primary types are stored. Inferred information is placed in brackets []. Type locality is given as a geographic position, not verbatim from the original description. 
Genus Heraclides Hübner, [1819]

Verz. bekannt. Schmett. (2): 83-84. Type species: Papilio thoas Linnaeus, 1771; designated by Scudder (1875) Proc. Am. Acad. Arts Sci., Boston 10(2): 187, no. 517 Subgenus Heraclides Hübner, [1819]

$=\dagger$ Thoas Swainson, 1833

Zool. Illustr. (2)3(26): pl. 121, unnumbered text. Type species: Papilio thoas Linnaeus, 1771 ; by tautonymy

cresphontes species group

Heraclides cresphontes Cramer, [1777] | Pap[ilio]. Equ[es]. Achiv[us]. Cresphontes | Eastern Giant Swallowtail

Uitl. Kapellen 2(14): 106-107, pl. 165 f. A 9 D\&V, pl. 166 f. B §̋ D (LT)| NT - USA: NY: Brooklyn; USNM

$=\dagger$ Heraclides Oxilus Hübner, [1819]

Verz. bek. Schmett. (2): 83 (replacement name for H. cresphontes)

$=\ddagger$ Papilio cresphontes ab. (nov.) lurida Schultz, 1908

Entomol. Z. 22(23): 92 | ST - "North America"; ? ; assignment to H. cresphontes is speculative

$=\ddagger$ Papilio thoas cresphontes ab. luxuriosa Reiff, 1911

Z. wiss. InsektBiol. 7(5/6): 159 | HT - USA: MI: Detroit; MCZ

$=\ddagger$ Papilio cresphontes ab. intacta Strand, 1918

Soc. Ent. 33(12): 47; referred to Seitz (1907) Gross-Schmett. Erde 5: pl. 7 f.

a [2] | ST - ?; ?

= Papilio cresphontes var. maxwelli Franck, 1919

Bull. Brooklyn Ent. Soc. 14(1): 3, f. 2 ๙ D (HT)| HT - USA: FL: Pinellas

Co., St. Petersburg; USNM

$=\ddagger$ Papilio cresphontes tr. f. forsythae Gunder, 1933

Can. Ent. 65(8): 171 | HT - USA: FL: Miami-Dade Co., Florida City; AMNH = Papilio cresphontes pennsylvanicus Chermock \& Chermock, 1945

Proc. Penn. Acad. Sci. 19: 38-39 | HT - USA: PA: Centre Co., State College; $\mathrm{CMNH}$

Heraclides rumiko Shiraiwa \& Grishin, 2014 | Heraclides rumiko | Western Giant Swallowtail

ZooKeys 468: 85-135 | HT - USA: TX: Duval Co., Benavides; USNM $=\ddagger$ Papilio cresphontes forma melanurus Hoffmann, 1940

An. Inst. Biol. Univ. Méx. 11(2): 633-634 |ST - Mexico, Guerrero; AMNH

Heraclides homothoas (Rothschild \& Jordan, 1906) | Papilio homothoas | False Giant Swallowtail

Novit. Zool. 13(3): 561-562, no. 67 | ST - Venezuela: Ciudad Bolivar, Lower Orinoco; BMNH

Heraclides melonius (Rothschild \& Jordan, 1906) | Papilio thoas melonius | Jamaican Giant Swallowtail

Novit. Zool. 13(3): 556, no. 66a | HT - Jamaica; BMNH 


\section{Discussion}

The Giant Swallowtail H. cresphontes is one of the largest butterflies in the United States, found mainly in the eastern US, from southern Canada to Florida and central Texas (Figs 14, 18). In this study, we assembled evidence that the North American southwest, from California to central Texas and south to Panama, is inhabited by its sister cryptic species (Bickford et al. 2007) that we named H. rumiko. It is rather unusual for such a large butterfly species to remain unnamed, at least as a subspecies, but its superficial similarity to $H$. cresphontes is a likely explanation. The two species differ from each other very subtly. They are mostly allopatric, and their ranges overlap in central Texas, around San Antonio and Austin, where both species are equally common and most likely hybridize (Fig. 11E). It is unclear why H. cresphontes does not disperse south and $H$. rumiko does not invade north, because they are excellent fliers and are likely to produce viable hybrids like many other Papilionidae do. In this section, we raise more speculative points about taxonomy, speciation, and evolution.

\section{Heraclides vs. Papilio s. 1.}

We follow Tyler et al. (1994) and Lamas (2004) in dividing Neotropical Papilionini into three genera: Papilio, Pterourus, and Heraclides. All recent studies show that these genera are monophyletic, can be defined by synapomorphies, and include sufficient number of species in each genus to be meaningful (Caterino and Sperling 1999, Zakharov et al. 2004, Simonsen et al. 2011). In some recent works, Papilio sensu lato is used as a genus that absorbs these three genera (Simonsen et al. 2011, Lewis at el. 2014). However, an unusual situation emerges when a subgenus name (i.e., Heraclides) is referred to more frequently in such works, and is therefore more instructive than the genus name. The level at which phylogenetic hierarchy is cut through to define genera is arbitrary and is for convenience of communication. Therefore, genera can be chosen as the most informative and major clades of species below the family and tribe levels. We think that for the New World representatives of the tribe Papilionini, Papilio, Pterourus, and Heraclides offer the most informative groupings, both from morphological and molecular standpoints.

First, divergence within each of the three genera is already very significant, reaching $10 \%$ sequence difference in the COI DNA barcode. In recent work on Lycaenidae, new criteria were proposed to delineate genera, i.e., "genera can be recognized as those lineages that originated in the late Miocene (older than 5 Myr)" (Talavera et al. 2012). Many of such genera differ by $6 \%$ and less in the barcodes. While we are not suggesting the use of a stringent universal time or DNA sequence difference threshold for genera identification, some consistency in genetic divergence across butterfly groups seems appealing. The age of Papilio s. 1. has been estimated at over $50 \mathrm{Myr}$ (Zakharov et al. 2004). Even the age of Heraclides was suggested to exceed $20 \mathrm{Myr}$ (Lewis et al. 2014). To put these estimates in perspective, divergence between Homo Linnaeus, 
1758 and Pan Oken, 1816 - the genus closest to Homo-is estimated to be about 10 Myr (Arnason et al. 1998) with COI barcode difference being about $10 \%$.

Second, each of the three Papilionini genera can be further divided into meaningful subgenera to denote finer groupings of species that correlate with phylogeny and morphology. For instance, in Heraclides, our analysis supports five subgenera (Fig. 15): Heraclides, Calaides, Troilides, Priamides, and Unnamed (consists of H. hyppason). Below the subgenus level, we also see instructive species groups, for instance, the Giant Swallowtails: Eastern (H. cresphontes), Western (H. rumiko), False (H. homothoas), and Jamaican (H. melonius), form a distinct cluster that can be recognized (Figs 15, 16). While we are not aiming to name every node in the tree, this three-level system (genus, subgenus, species group) for Papilionini covers major phylogenetic clades and may be sufficient.

Third, the most important utility about using the three genera instead of Papilio s.l. is the gain of a taxonomic hierarchy level to describe complex phylogenetic relationships within Papilionini. When Papilio s.l. is used, it equates to the tribe (tribe = one genus) and we essentially lose a classification level and thus the ability to describe the finer phylogenetic structure of the tree by names. For all these reasons, we think that the simple three-genus system of the native New World Papilionini will stand the test of time.

\section{Species vs. subspecies}

In contrast to genus, species is a more objective biological category. A number of species concepts has been proposed (De Queiroz 2007), with the most popular one being biological. A species is a group of populations capable of interbreeding, but reproductively isolated from all other such groups (Mayr 1963: 12, 14). However, if this concept was truly objective and evolutionary processes stood still, there would be few arguments about species boundaries. Due to ongoing speciation, some groups of populations are in transition. It is very challenging, if not impossible, to decide if they fully crossed the speciation barrier, i.e., developed certain incompatibilities that prevent interbreeding. Additional complexities are caused by the fact that many different species can readily hybridize when opportunities allow (Mallet 2008, Zinner et al. 2011). It is frequently difficult to determine whether the hybrids are characterized by reduced fitness and what amount of fitness loss in hybrids equates complete speciation. Moreover, recent developments in genomics suggest that inter-species hybridization may play a very significant role in evolution, giving an opportunity for closely related species to exchange advantageous genes, e.g., those responsible for mimicry (Heliconius Genome Consortium 2012).

While hybridization experiments followed by fitness measurements in hybrids and backcrosses may be decisive in delineating species boundaries, phenotypic differences and genetic divergence are used as more practical criteria. If two populations of the same species have spent significant time in isolation, mutations randomly accumulating 
in them are likely to cause incompatibilities upon interbreeding, leading to speciation. Some mutations may also cause phenotypic effects, allowing researchers to recognize species by morphological characters. Gene regions rich in neural mutations, such as the COI barcode, are used as yardsticks to estimate divergence between populations. Larger divergence between populations indicates higher chance of speciation. No universal threshold for divergence to mean speciation is possible. Recently formed species may have identical DNA barcodes. High barcode variability within population may lead to conspecific individuals with large barcode differences. To derive sensible conclusions, comparison of barcode variation within and between populations is necessary. Since similar evolutionary mechanisms frequently occur in related organisms, evaluation of barcode variability across the genus is desirable. Finally, correlation between DNA differences and morphological differences is most effective for delineation of species.

In many animals, allopatric populations of the same species characterized by measurable morphological differences, such as those in shapes and colors, are frequently named as subspecies. Typically, subspecies diverged in morphology very recently. Therefore, differences between their DNA barcodes are small compared to those between species. Some of these subspecies are on a path to speciation. Given longer time, and thus more mutations accumulating in the DNA barcode, reproductive incompatibility between these populations will arise. Random extinctions of various populations prune phylogenetic tree and lead to formation of discrete clades that form various clusters. Comparative analysis of these clades and clusters suggests taxonomic hypotheses.

We applied these ideas to selected Neotropical representatives of the tribe Papilionini (Fig. 15-17). We see that differences between subspecies (nodes leading to subspecies are colored green) are mostly within $1.0 \%$. For instance, Pt. glaucus glaucus (Linnaeus, 1758) and Pt. glaucus maynardi (Gauthier, 1984) barcodes differ by $0.2 \%$, or just 1 base pair. On the other hand, differences between species (nodes leading to species are colored red) are typically above $2 \%$. For example, barcode of Pt. glaucus glaucus differs from barcode of Pt. canadensis (Rothschild \& Jordan, 1906) by $2.1 \%$, or $14 \mathrm{bp}$. We noticed several instances of taxa previously treated as subspecies with barcode differences between $2.5 \%$ and $5.2 \%$ from their respective nominate subspecies (names highlighted orange in Fig. 15). Analysis of their genitalia revealed differences comparable in magnitude to those characteristic of species. Combining the evidence from wing patterns, genitalia and DNA barcodes, we proposed species status for these taxa, as detailed in the Results section.

DNA barcodes of $H$. cresphontes and $H$. rumiko show less than $0.5 \%$ difference within each species, but differ by $2.9 \%$ between them (Figs 15-17). This difference is comparable to those between other pairs of closely related species in Papilionini, e.g., $H$. ornythion vs. $H$. pallas $(2.6 \%), H$. androgeus vs. $H$. thersites $(2.9 \%)$, and $H$. multicaudata vs. $H$. canadensis $(2.8 \%)$, but significantly larger than differences between subspecies, e.g., of $H$. androgeus (0.3\%-1.1\%), $H$. torquatus $(0.6 \%-1.1 \%)$, and $H$. anchisiades $(<0.2 \%)$. H. cresphontes and $H$. rumiko differ in male genitalia, and most specimens can be told apart by spots vs. stripes on the neck, wing shape, and wing patterns. Therefore we proposed $H$. rumiko as a species. However, it is clear that it is 
a close sister to $H$. cresphontes, and the two together may be considered a superspecies (Amadon 1966).

Distribution ranges of $H$. cresphontes and $H$. rumiko overlap in central Texas, mostly from Austin to Houston and San Antonio. The two species almost certainly hybridize where they meet. We see that some individuals from the overlap zone show intermediate characteristics and are probable hybrids (Fig. 11E). Despite probable interbreeding, the two taxa maintain integrity and do not absorb each other expanding the overlap zone, which suggests certain reproductive isolation. It is likely that their hybrids are characterized by reduced fitness, preventing the expansion of the overlap zone and free mixing of individuals across the entire ranges of the two species. The absence of broader overlap zone between the two haplotypes and the lack of variability in DNA barcodes within each species over thousands of miles is congruent with the genomic integrity species concept of Sperling (2003). This situation reminds one of the relationships between Pt. canadensis and Pt. glaucus, two species showing a $2.1 \%$ difference in the DNA barcode and diverged about 600,000 years ago (Zhang et al. 2013). This pair also has an overlap zone with frequent hybridization between species. Examples of different animal species that hybridize in parts of their ranges are not uncommon, and exist even in vertebrates. For instance, coyotes can interbreed with several species of wolves and descendants of these hybrids are known as coywolves (Hailer and Leonard 2008). Further study of how $H$. cresphontes and $H$. rumiko interact in the overlap zone is expected to yield insights into the mechanisms of speciation, isolation and maintenance of species integrity in the presence of hybridization.

Ultimately, there is no proof, but a hypothesis_or prediction — that we think has a better chance of standing the test of time. Given all the information we assembled, our bet is on the species (and not subspecies) status of $H$. rumiko, which offers a treatment more consistent with how other Papilionini are currently classified (Lamas 2004, Pelham 2008, Warren et al. 2014).

As a summary, we observe three levels of differentiation at and near the species level. First, there are clusters of populations with small genetic differences between them (mostly within 1\% in COI barcodes, sometimes no difference at all), but certain geographic differences in wing patters. These populations could be defined as subspecies. Next, there are groups with larger genetic differences (typically above $2 \%$ in COI barcodes, but could be less), frequently characterized by measurable differences in genitalia. These groups could be called species. Finally, several mostly allopatric species characterized by closely related phenotypes form very distinct genotypic groups (usually more than $5 \%$ in COI barcodes) could be termed a superspecies. All these levels are seen in Heraclides (Fig. 15).

\section{Evolutionary speculations}

The 3\% difference in DNA barcodes of $H$. cresphontes and $H$. rumiko suggests that the two species diverged between 1 and 3 million years ago (April et al. 2013, Papado- 


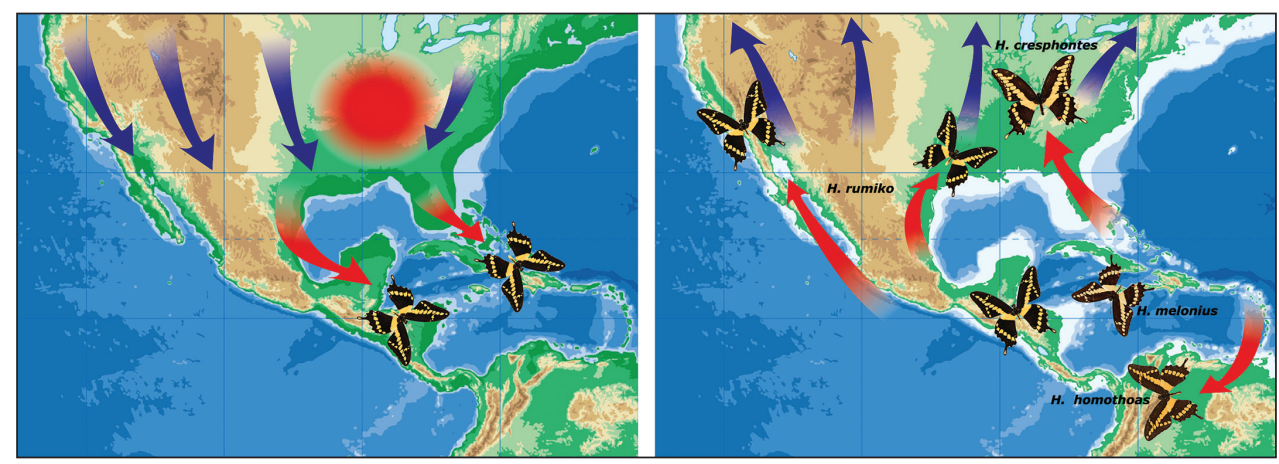

Figure 25. Speculations about origins of the $H$. cresphontes group species. Left panel: Ancestor of $H$. cresphontes might have originated in eastern North America (red area), speciating from a more southern $H$. thoas. During Pleistocene, glaciation and cooler climate (blue arrows) forced $H$. cresphontes ancestor south through two possible paths: to Mexico and to Florida-Caribbean islands (red arrows). Resulting populations got isolated and differentiated into four species. Right panel: With retreat of glaciation (blue arrows), eastern $H$. cresphontes moved back to eastern North America; southwestern H. rumiko moved north through west and east Mexico; H. melonius got trapped and speciated further in Jamaica. H. homothoas probably evolved in northern South America arriving from the Caribbean islands through Trinidad and moved north to Costa Rica thus overlapping with H. rumiko in distribution.

poulou et al. 2009, Zhang et al. 2013). We hypothesize that the speciation of the H. cresphontes group is linked to the Pleistocene glaciation (Fig. 25). Prior to glaciation, certain events lead to formation of the $\mathrm{H}$. thoas group ancestor, probably the southern lineage, and the $\mathrm{H}$. cresphontes group ancestor, probably the northern lineage inhabiting the territory of present-day USA. Formation of ice sheets from the north and colder climate gradually drove $H$. cresphontes populations south, dividing them into at least two groups. One group escaped into Mexico, and the other one was cornered in Florida and the Caribbean Islands, and, though them, went into South America. Due to lower sea levels, the Islands were larger and more accessible from the continent than they are today. Geographic isolation of these $H$. cresphontes-like populations resulted in the four species. Populations on Jamaica lead to H. melonius. South American populations speciated into $H$. homothoas. Floridian populations gave rise to $H$. cresphontes. Mexican, and probably the largest, segments developed into $H$. rumiko. With the ice retreat, species started to spread north. H. homothoas invaded Central America, H. cresphontes took most of the former range of the $\mathrm{H}$. cresphontes group ancestor in eastern US, and met with $H$. rumiko in central Texas.

\section{Limited dispersal and a need for USDA regulation}

In our medium-scale barcoding study we didn't see any significant invasion of $H$. cresphontes and H. rumiko into each other's ranges (Fig. 18). Eastern populations were $H$. cresphontes and southwestern populations were $H$. rumiko. Specimens with both 
barcodes were present only in central Texas. However, these butterflies are strong fliers and are known to travel long distances, even being somewhat migratory (Pyle 1981, Scott 1986). Most of the migratory movements seem to be directed north. One may assume that $H$. rumiko might fly from Texas northwards into the Great Plains. Nevertheless we have not found any H. rumiko specimens northeast of Texas. The northward movement in California seems to be also rare, perhaps due to the drier climate and lack of the host plants. Equally, we do not observe very frequent invasion of $H$. cresphontes to the west. Apparently, such dispersals are not common, and the two species remain mostly confined to their respective ranges. However, there is some indication that a limited dispersal takes place, shown by the two barcoded records outside the regular range of the two species: northern WY and northeastern $\mathrm{CO}$, which were $H$. cresphontes and $H$. rumiko by the barcodes, respectively.

"Giant Swallowtail" is one of the species used in butterfly release ceremonies across the US. USDA lists $H$. cresphontes as one of the nine species of butterflies that can be transported across state lines and released into the wild under a permit (USDA 2012). Immature stages of $H$. cresphontes are available for purchase on the internet, ready to be shipped from one region of the country to another. Now, since we have shown that $H$. cresphontes is the species that is confined in its distribution to the eastern US (east of $100^{\text {th }}$ Meridian), and $H$. rumiko is the southwestern US species, east-west movements of Giant Swallowtails should be controlled similarly to the Monarch (Danaus plexippus (Linnaeus, 1758)). In fact, we think that the Giant Swallowtail regulation will be more useful than the Monarch regulation, because of limited natural dispersal of the two Heraclides species. It may be important to discourage transport of Giant Swallowtails across $100^{\text {th }}$ Meridian to prevent unnecessary mixing of the two species. That said, we do not favor the extreme step of shutting releases down, and firmly believe in collaboration between butterfly farmers, environmentalists, enthusiasts, and researchers. Butterfly releases increase awareness of nature and invertebrates, especially among peo-

ple who may not otherwise be interested in insects. Thus releases serve an educational value, which should not be let go. Unless release practice reaches astronomically large proportions, their impact on natural insect populations will remain negligibly small.

\section{Acknowledgments}

Qian Cong is a Howard Hughes Medical Institute International Student Research fellow. We thank Texas Parks and Wildlife Department (Natural Resources Program Director David H. Riskind) for the permit \#08-02Rev making research based on material collected in Texas State Parks possible. We are grateful to Edward G. Riley (Texas A \& M University insect collection, College Station, TX), Brian Harris, Robert K. Robbins, and John M. Burns (National Museum of Natural History, Smithsonian Institution, Washington DC), James R. Reddell (University of Texas at Austin Insect Collection, Austin, TX), Paul A. Opler (Colorado State University Collection, Fort Collins, CO), Rebekah Shuman Baquiran (The Field Museum of Natural History, 
Chicago, IL), David Grimaldi and Lesley Thayer (American Museum of Natural History, New York, NY), Andrew D. Warren (McGuire Center for Lepidoptera and Biodiversity, Gainesville, FL), John Chainey, David Lees, and Blanca Huertas (Natural History Museum, London, UK), Michael Wall and Jim Berrian (San Diego Natural History Museum, San Diego, CA), and Brian Brown (Los Angeles County Natural History Museum, Los Angeles, CA), for facilitating access to the collections under their care, loans of specimens, and stimulating discussions; to Rob de Vos (Naturalis Biodiversity Center, Leiden, Netherlands) fo8565r search for possible $H$. cresphontes syntypes; to Jonathan P. Pelham for fruitful discussions, encouragement and assistance in obtaining difficult to find papers; to Delano Lewis for help and generously sharing his expert knowledge of Heraclides swallowtails; to Bill Dempwolf, Dale Clark, Jim P. Brock, and Mark Walker for Heraclides specimens much needed for the analysis; to Jeremy Kuhn for Papilionidae legs, data and specimens; to Floyd and June Preston for collecting $H$. homothoas in Venezuela over 60 years ago and flawlessly storing the specimens in glassine envelopes for all these years; to Gerardo Lamas for the photographs of a possible $H$. cresphontes syntype, discussions, and advice; to Michelle Warren, who generously provided $H$. rumiko eggs from her home in San Diego for rearing; to Paul Opler for all the help, encouragements, review of the manuscript, and corrections; and to Brian Banker for reading the manuscript, information, and edits, and to the reviewers for helpful comments and suggestions. Without everyone's help, we would have never finished this work.

\section{References}

Altschul SF, Gish W, Miller W, Myers EW, Lipman DJ (1990) Basic local alignment search tool. Journal of Molecular Biology 215(3): 403-410. doi: 10.1016/S0022-2836(05)80360-2

Amadon D (1966) The superspecies concept. Systematic Biology 15(3): 245-249. doi: 10.2307/sysbio/15.3.245

April J, Hanner RH, Mayden RL, Bernatchez L (2013) Metabolic rate and climatic fluctuations shape continental wide pattern of genetic divergence and biodiversity in fishes. PLoS One 8(7): e70296. doi: 10.1371/journal.pone.0070296

Arnason U, Gullberg A, Janke A (1998) Molecular timing of primate divergences as estimated by two nonprimate calibration points. Journal of Molecular Evolution 47(6): 718-727. doi: 10.1007/PL00006431

Benson DA, Clark K, Karsch-Mizrachi I, Lipman DJ, Ostell J, Sayers EW (2014) GenBank. Nucleic Acids Research 42: 32-37. doi: 10.1093/nar/gkt1030

Bickford D, Lohman DJ, Sodhi SH, Ng PKL, Meier R, Winker K, Ingram KK, Das I (2007) Cryptic species as a window on diversity and conservation. Trends in Ecology \& Evolution 22(3): 148-155. doi: 10.1016/j.tree.2006.11.004

Bremer K (1994) Branch support and tree stability. Cladistics 10: 295-304. doi: 10.1111/ j.1096-0031.1994.tb00179.x

Brown FM (1964) Tryon Reakirt (1844-?). Journal of the Lepidopterists' Society 18 (4): 211-214. 
Caterino MS, Sperling FAH (1999) Papilio Phylogeny Based on Mitochondrial Cytochrome Oxidase I and II Genes. Molecular Phylogenetics and Evolution 11(1): 122-137. doi: 10.1006/mpev.1998.0549

Chainey JE (2005) The species of Papilionidae and Pieridae (Lepidoptera) described by Cramer and Stoll and their putative type material in the Natural History Museum in London. Zoological Journal of the Linnean Society 145: 283-337. doi: 10.1111/j.10963642.2005.00184.x

Chermock FH, Chermock RL (1945) Two new races of North American butterflies. Proceedings of the Pennsylvania Academy of Science 19: 38-39.

Clench HK, Miller LD (1980) Papilio ladon Cramer vs. Argus pseudargiolus Boisduval and Deconte (Lycaenidae): a nomenclatorial nightmare. Journal of the Lepidopterists' Society 34(2): 103-119.

Cockerell TDA (1927) A new subspecies of Papilio paeon (Lepid.). Proceedings of the entomological Society of Washington 29(2): 48.

Cramer P (1777) De uitlandische Kapellen voorkomende in de drie Waereld-Deelen Asia, Africa en America. Papillons exotiques des trois parties du monde l'Asie, l'Afrique et l'Amérique. S. J. Baalde; Utrecht, Barthelemy Wild and J. Van Schoonhoven \& Comp., Amsteldam 2(9-16): 1-151.

Daubenton LJM ([1765]) [Miscellanea.] Author, Paris, (3): pls. 50-73 (engr. Martinet et al.).

De Queiroz K (2007) Species concepts and species delimitation. Systematic Biology 56(6): 879-886. doi: 10.1080/10635150701701083

Dereeper A, Guignon V, Blanc G, Audic S, Buffet S, Chevenet F, Dufayard JF, Guindon S, Lefort V, Lescot M, Claverie JM, Gascuel O (2008) Phylogeny.fr: robust phylogenetic analysis for the non-specialist. Nucleic Acids Research 36: 465-469. [Web Server issue]

Drury D (1770) Illustrations of Natural History. B. White, London, 130 pp. [23 April, 1770]

Dwight WB (1882) The domestication of Papilio thoas (cresphontes) in Dutches, N.Y. Psyche, 327 pp. doi: $10.1155 / 1882 / 17467$

Emmel TC, Emmel JF (1973) The Butterflies of Southern California. Natural History Museum of Los Angeles County, Los Angeles, 148 pp.

Emmel TC (1986) Status survey and habitat requirements of Florida's endemic Schaus swallowtail butterfly. Florida Game and Fresh Water Fish Commission, Final Report GFC84-028. Tallahassee, Florida.

Erickson RA, Iliff MJ (2004) Occurrence of the Giant Swallowtail (Papilio cresphontes) in Northern Baja California. The Southwestern Naturalist 49(4): 506-538. doi: 10.1894/0038-4909(2004)049<0506:OOTGSP>2.0.CO;2

Franck G (1919a) Papilio cresphontes, var. maxwelli, nov. Bulletin of the Brooklyn Entomological Society 14(1): 3 .

Franck G (1919b) Papilio cresphontes, var. maxwelli Franck. Bulletin of the Brooklyn Entomological Society 14(3): 101.

Gascuel O (1997) BIONJ: an improved version of the NJ algorithm based on a simple model of sequence data. Molecular Biology and Evolution 14(7): 685-695. doi: 10.1093/oxfordjournals.molbev.a025808 
Godart JB (1819) Pp. 13-328. In: Latreille PA, Godart JB (Eds) Encyclopédie Méthodique. Histoire naturelle. Entomologie, ou histoire naturelle des crustacés, des arachnides et des insectes. Paris, veuve Agasse 9(1): 3-328.

Goloboff PA, Farris JS, Nixon KC (2008) TNT, a free program for phylogenetic analysis. Cladistics 24: 1-13. doi: 10.1111/j.1096-0031.2008.00217.x

Grimshaw PH (1897) On some type specimens of Lepidoptera and Coleoptera in the Edinburgh Museum of Science and Art. Proceedings of the Royal Society of Edinburgh 21: 326-327.

Hagen RH, Lederhouse RC, Bossart JL, Scriber JM (1991) Papilio canadensis and P. glaucus are distinct species. Journal of the Lepidopterists' Society 45(4): 245-258.

Hailer F, Leonard JA (2008) Hybridization among three native North American Canis species in a region of natural sympatry. PLoS One 3(10): e3333. doi: 10.1371/journal. pone. 0003333

Hebert PDN, deWaard JR, Landry J-F (2010) DNA barcodes for 1/1000 of the animal kingdom. Biology Letters 6(3): 359-362. doi: 10.1098/rsbl.2009.0848

Heliconius Genome Consortium (80 Collaborators) (2012) Butterfly genome reveals promiscuous exchange of mimicry adaptations among species. Nature 487(7405): 94-98.

Hoffmann CC (1940) Lepidópteros nuevos de México. V. Anales del Instituto de Biología. Universidad nacional de México 11(2): 633-638.

Holland WJ (1898) The butterfly book: a popular guide to a knowledge of the butterflies of North America. Doubleday \& McClure Co., New York, 382 pp.

Honey MR, Scoble MJ (2001) Linnaeus' butterflies (Lepidoptera: Papilionoidea and Hesperioidea). Zoological Journal of the Linnean Society 132(3): 277-399. doi: 10.1111/j.10963642.2001.tb01326.x

Huelsenbeck JP, Ronquist F (2001) MRBAYES: Bayesian inference of phylogeny. Bioinformatics 17: 754-755. doi: 10.1093/bioinformatics/17.8.754

ICZN (International Commission on Zoological Nomenclature) (1999) International Code of Zoological Nomenclature, Fourth Edition. International Trust for Zoological Nomenclature, London, xxix + 306 pp. Online version amended "with effect from 1 January 2012". http://www.nhm.ac.uk/hosted-sites/iczn/code/ [accessed January 12, 2014]

Kawahara AY, Breinholt JW (2014) Phylogenomics provides strong evidence for relationships of butterflies and moths. Proceedings of the Royal Society B 281(1788). doi: 10.1098/ rspb.2014.0970

Klotz AB (1956) Lepidoptera. In: Tuxen SL (Ed.) Taxonomists' glossary of genitalia in insects. Munksgaard, Copenhagen, 115-130.

Kunte K, Shea C, Aardema ML, Scriber JM, Juenger TE, Gilbert LE, Kronforst MR (2011) Sex chromosome mosaicism and hybrid speciation among tiger swallowtail butterflies. PLoS Genetics 7(9): e1002274. doi: 10.1371/journal.pgen.1002274

Kunte K, Zhang W, Tenger-Trolander A, Palmer DH, Martin A, Reed RD, Mullen SP, Kronforst MR (2014) doublesex is a mimicry supergene. Nature 507(7491): 229-232. doi: $10.1038 /$ nature 13112

Lamas G (2004) Papiliondae. In: Heppner JB (Ed.) Checklist: Part 4A. Hesperioidea-Papilionoidea. Atlas of Neotropical Lepidoptera. Association for Tropical Lepidoptera/Scientific Publishers, Gainesville, 220 pp. 
Laszlo P (2007) Citrus: a history. The University of Chicago Press, Chicago, 262 pp.

Lewis DS (2010) Phylogeny and revision of the genus Heraclides Hübner, 1819 (Lepidoptera: Papilionidae: Papilioninae: Papilionini). University of Florida, Doctoral dissertation.

Lewis DS, Sperling FAH, Nakahara S, Cotton AM, Kawahara AY, Condamine FL (2014) Role of Caribbean Islands in the diversification and biogeography of Neotropical Heraclides swallowtails. Cladistics. doi: 10.1111/cla.12092

Linnaeus C (1771) Regni animalis, Appendix. Insecta. Mantissa plantarum altera generum editionis VI \& specierum editionis II. Holmiae, Laurentius Salvius, 529-543.

Mallet J (2008) Hybridization, ecological races and the nature of species: empirical evidence for the ease of speciation. Philosophical Transactions of the Royal Society B: Biological Sciences 363(1506): 2971-2986. doi: 10.1098/rstb.2008.0081

Mayr E (1963) Animal species and evolution. Harvard University Press, Cambridge, 811 pp. doi: 10.4159/harvard.9780674865327

Miller JS (1987) Phylogenetic studies in the Papilioninae (Lepidoptera: Papilionidae). Bulletin of the American Museum of Natural History 186(4): 367-512.

Miller LD, Brown FM (1981) A catalogue/checklist of the butterflies of America north of Mexico. Memoir. The Lepidopterists' Society 2: 1-280.

Molina A, León JL (2006) Movilidad y Especialización Ecológica Como Variables que Afectan la Abundancia y Distribución de Lepidópteros Papilionidos en El Sumidero, Chiapas, México. Acta Zoológica Mexicana (NS) 22 (3): 29-52.

Ording GJ (2008) An analysis of climate induced hybrid speciation in Tiger Swallowtail butterflies (Papilio). PhD dissertation, Michigan State University, Ann Arbor.

Ording GJ, Mercader RJ, Aardema ML, Scriber JM (2009) Allochronic isolation and incipient hybrid speciation in tiger swallowtail butterflies. Oecologia 162(2): 523-531. doi: 10.1007/ s00442-009-1493-8

Papadopoulou A, Anastasiou I, Vogler AP (2009) Revisiting the insect mitochondrial molecular clock: the mid-Aegean trench calibration. Molecular Biology and Evolution 27: 1659-1672. doi: 10.1093/molbev/msq051

Pavulaan H, Wright DM (2002) Pterourus appalachiensis (Papilionidae: Papilioninae), a new swallowtail butterfly from the Appalachian region of the United States. Taxonomic Report of the International Lepidoptera Survey 3(7): 1-10.

Pelham JP (2008) A catalogue of the butterflies of the United States and Canada with a complete bibliography of the descriptive and systematic literature. Journal of Research on the Lepidoptera 40: 1-652.

Pyle R (1981) The Audubon Society field guide to North American butterflies. Knopf, New York, $916 \mathrm{pp}$.

Ratnasingham S, Hebert PDN (2007) BOLD : The Barcode of Life Data System (www. barcodinglife.org). Molecular Ecology Notes 7(3): 355-364. doi: 10.1111/j.14718286.2007.01678.x

Robbins RK (1991) Evolution, comparative morphology, and identification of the Eumaeine butterfly genus Rekoa Kaye (Lycaenidae: Theclinae). Smithsonian Contributions to Zoology 498: 1-64. Ronquist F, Huelsenbeck JP (2003) MRBAYES 3: Bayesian phylogenetic inference under mixed models. Bioinformatics 19: 1572-1574. doi: 10.1093/bioinformatics/btg180 
Rothschild W, Jordan K (1906) A revision of the American Papilios. Novitates zoologicae 13(3): 411-752.

Scott J (1986) The butterflies of North America. Stanford University, Stanford, 583 pp.

Shiraiwa K (2009) The Butterflies of San Diego County. Self-published, San Diego, 74 pp.

Simonsen TJ, Zakharov EV, Djernaes M, Cotton AM, Vane-Wright RI, Sperling FAH (2011)

Phylogenetics and divergence times of Papilioninae (Lepidoptera) with special reference to the enigmatic genera Teinopalpus and Meandrusa. Cladistics 27(2): 113-137. doi: 10.1111/j.1096-0031.2010.00326.x

Shull EM (1987) The butterflies of Indiana. Indiana University Press, Bloomington, 262 pp.

Sperling FAH (2003) Butterfly molecular systematics: from species definitions to higher level phylogenies. In: Boggs C, Ehrlich P, Watt W (Eds) Ecology and Evolution Taking Flight: Butterflies as Model Study Systems. University of Chicago Press, Chicago, 431-458.

Sperling FAH, Harrison RG (1994) Mitochondrial DNA variation within and between species of the Papilio machaon group of swallowtail butterflies. Evolution 48(2): 408-422. doi: 10.2307/2410101

Stamatakis A (2006) RAxML-VI-HPC: maximum likelihood-based phylogenetic analyses with thousands of taxa and mixed models. Bioinformatics 22(21): 2688-2590. doi: 10.1093/ bioinformatics/btl446

Talavera G, Lukhtanov VA, Pierce NE, Vila R (2012) Establishing criteria for higher-level classification using molecular data: the systematics of Polyommatus blue butterflies (Lepidoptera, Lycaenidae). Cladistics 29(2): 166-192. doi: 10.1111/j.1096-0031.2012.00421.x

Tyler HA, Brown Jr KS, Wilson KH (1994) Swallowtail butterflies of Americas / a study in biological dynamics, ecological diversity, biosystematics and conservation. Scientific Publishers, Inc., Gainesville, 376 pp.

USDA (2012) USDA AHIS-PPQ Butterfly Environmental Release Decision Chart, Version 11, April 13, 2012. http://www.aphis.usda.gov/plant_health/permits/organism/downloads/decision_chart.pdf [Accessed: 13 March 2014]

Warren AD, Davis KJ, Stangeland EM, Pelham JP, Grishin NV (2014) Illustrated Lists of American Butterflies. http://www.butterfliesofamerica.com [28-IX-2014]

Winter CB, Porter AH (2010) AFLP linkage map of hybridizing swallowtail butterflies, Papilio glaucus and Papilio canadensis. Journal of Heredity 101(1): 83-90. doi: 10.1093/jhered/ esp067

Zakharov EV, Caterino MS, Sperling FA (2004) Molecular phylogeny, historical biogeography, and divergence time estimates for swallowtail butterflies of the genus Papilio (Lepidoptera: Papilionidae). Systematic Biology 53(2): 193-215. doi: 10.1080/10635150490423403

Zakharov EV, Lobo NF, Nowak C, Hellmann JJ (2009) Introgression as a likely cause of mtDNA paraphyly in two allopatric skippers (Lepidoptera: Hesperiidae). Heredity (Edinburgh) 102(6): 590-599. doi: 10.1038/hdy.2009.26

Zhang W, Kunte K, Kronforst MR (2013) Genome-wide characterization of adaptation and speciation in tiger swallowtail butterflies using de novo transcriptome assemblies. Genome Biology and Evolution 5(6): 1233-1245. doi: 10.1093/gbe/evt090

Zinner D, Arnold ML, Roos C (2011) The strange blood: natural hybridization in primates. Evolutionary Anthropology 20(3): 96-103. doi: 10.1002/evan.20301 


\section{Supplementary material I}

\section{Supplementary Table 1}

Authors: Kojiro Shiraiwa, Qian Cong, Nick V. Grishin

Data type: specimen data.

Explanation note: Data for specimens with DNA sequences determined in this study. Copyright notice: This dataset is made available under the Open Database License (http://opendatacommons.org/licenses/odbl/1.0/). The Open Database License $(\mathrm{ODbL})$ is a license agreement intended to allow users to freely share, modify, and use this Dataset while maintaining this same freedom for others, provided that the original source and author(s) are credited. 